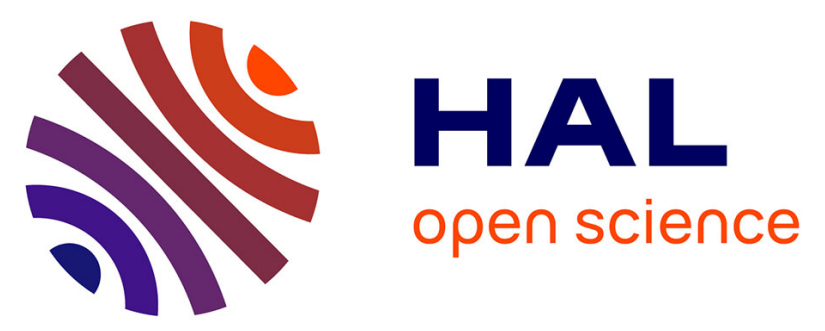

\title{
Subchronic exposure to high-density polyethylene microplastics alone or in combination with chlortoluron significantly affected valve activity and daily growth of the Pacific oyster, Crassostrea gigas
}

Arno Bringer, Hélène Thomas, Emmanuel Dubillot, Stéphane Le Floch, Justine Receveur, Jérôme Cachot, Damien Tran

\section{To cite this version:}

Arno Bringer, Hélène Thomas, Emmanuel Dubillot, Stéphane Le Floch, Justine Receveur, et al.. Subchronic exposure to high-density polyethylene microplastics alone or in combination with chlortoluron significantly affected valve activity and daily growth of the Pacific oyster, Crassostrea gigas. Aquatic Toxicology, 2021, 237, pp.105880. 10.1016/j.aquatox.2021.105880 . hal-03434008

\author{
HAL Id: hal-03434008 \\ https://hal.science/hal-03434008
}

Submitted on 23 Nov 2021

HAL is a multi-disciplinary open access archive for the deposit and dissemination of scientific research documents, whether they are published or not. The documents may come from teaching and research institutions in France or abroad, or from public or private research centers.
L'archive ouverte pluridisciplinaire HAL, est destinée au dépôt et à la diffusion de documents scientifiques de niveau recherche, publiés ou non, émanant des établissements d'enseignement et de recherche français ou étrangers, des laboratoires publics ou privés. 
1 Subchronic exposure to high-density polyethylene microplastics alone or in combination

2 with chlortoluron significantly affected valve activity and daily growth of Crassostrea gigas.

3

4 Arno Bringer $^{1^{*}}$, Hélène Thomas ${ }^{1+}$, Emmanuel Dubillot $^{1}$, Stéphane Le Floch ${ }^{3}$, Justine Receveur ${ }^{3}$, Jérôme 5 Cachot $^{2+}$, Damien $\operatorname{Tran}^{2}$

6

${ }^{1}$ Littoral Environnement et Sociétés (LIENSS), UMR 7266, CNRS-Université de La Rochelle, 2 rue Olympe de Gouges, F-17042 La Rochelle Cedex 01, France.

$9 \quad{ }^{2}$ Université de Bordeaux, CNRS, EPOC, EPHE, UMR 5805, F-33600 Pessac, France.

$10{ }^{3}$ Cedre, 715 Rue Alain Colas, 29218 Brest Cedex 2, France.

$11+$ : equal contributions

$12 \quad$ *: Corresponding author: Arno Bringer: Tel: +33 645299739 (FR), Email: arno.bringer1@univ-Ir.fr

14 Abstract

15 Nowadays, pesticides and microplastics (MPs) are commonly found in coastal waters worldwide. Due 16 to their widespread use, their persistence and toxicity, they may induce adverse effects on 17 physiology and behaviour of marine organisms such as the Pacific oyster (Crassostrea gigas). This 18 study explored the growth and valve activity of juvenile oysters exposed for 24 days to two 19 frequently detected pollutants in the Pertuis Charentais (South-West France): an herbicide

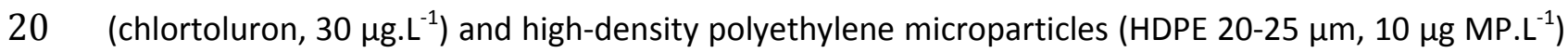
21 alone or in combinaison. The characterisation of the valve activity of juvenile oysters, recorded by using a High Frequency and Non-Invasive valvometer (HFNI) depended on three parameters: the number of valve micro-closures (VMC), the Valve Opening Amplitude (VOA) and the Valve Opening

24 Duration (VOD). Additionally, daily shell growth and the oyster daily rhythm were assessed. The 25 exposure to MPs of oysters leaded to a significant, increase of VMC and a decrease of VOD and shell 26 growth. The exposure to chlortoluron showed a significant, increase of VOA and a decrease of VMC. 
27 In mixture with MPs, chlortoluron still increased VOA and decreased VMC but also reduced the shell

28 growth. Chronobiological analysis did not reveal any effects on the daily rhythm of both

29 contaminants. High experimental concentrations of MP and chlortoluron were tested. This work has underlined their selective impacts on the behavioral and physiological parameters studied.

31

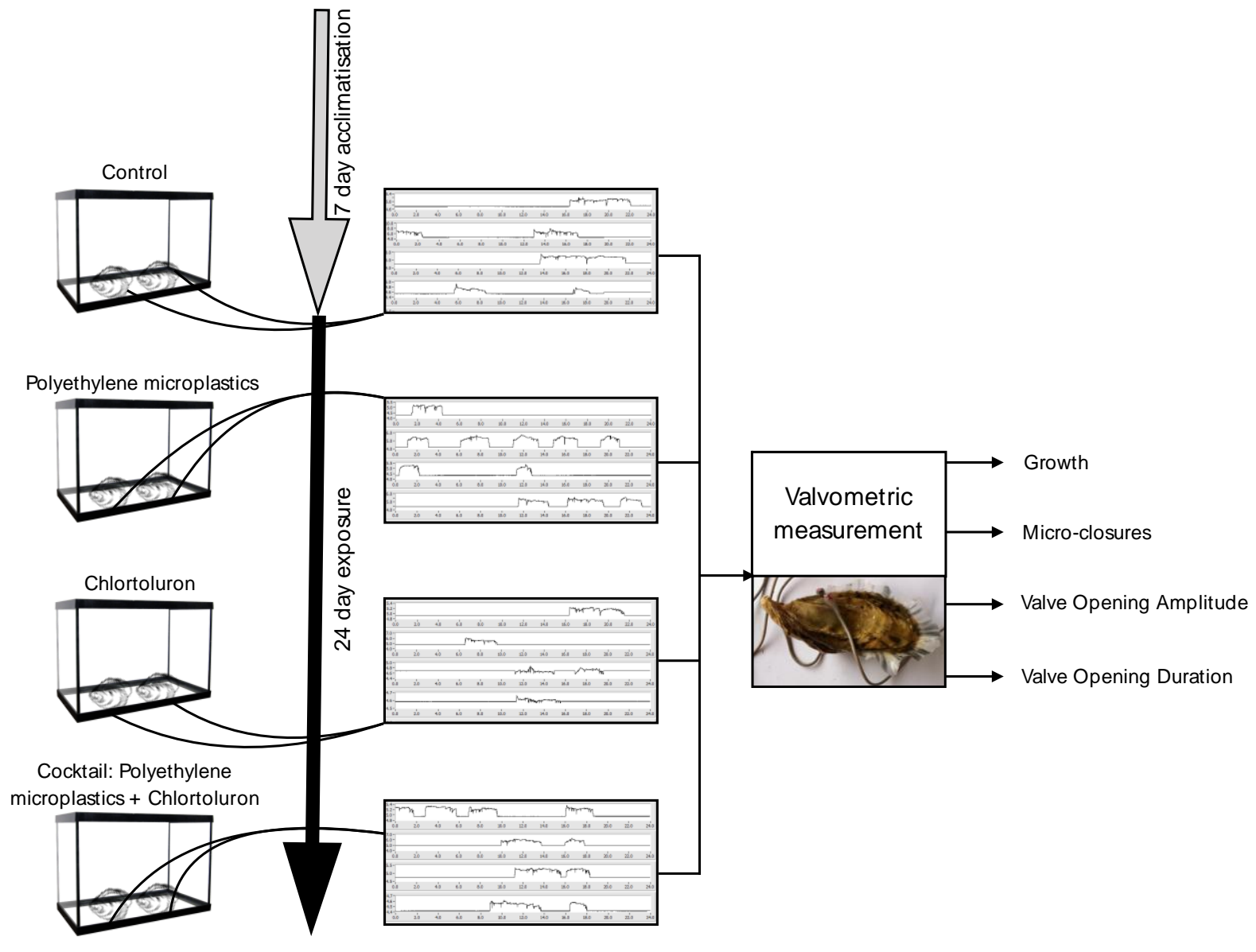

Keywords Bivalve molluscs, Experimental biomonitoring, Microplastics, Pesticide, Valve behaviour,

Growth. 
With a production of 135,000 tons of bivalves in 2017 , including 81,000 tons of oysters, France, is the $2^{\text {nd }}$ most important producer of bivalves in Europe (France Agrimer, 2020). Shellfish farming turnover

41 was estimated at 774 million euros in 2019 (CNC, 2020). The Pertuis Charentais area (South-West, Atlantic coast, France) represents $23 \%$ of the national oyster production (CNC, 2016). Since 2010, juvenile and adult oysters are facing excess mortality rates, reaching 70 to $80 \%$ of oyster farms located in the Atlantic coast (Soletchnik et al., 2018 ; Lucasson, 2018 and Girard \& Agundez, 2014). The quality of the coastal waters, where bivalves are grown, is a source of concern today. The increased use of plastics (Phuong, 2018) in aquaculture generates MPs pollution, which could affect physiology of bivalves (e.g. growth, immune status, reproduction) (Sussarellu et al., 2016; Paul-Pont et al., 2018; Gardon et al., 2020). Scientific studies are working to offer more and more toxicological tests on emerging contaminants such as MPs and pesticides, in order to better understand the modes of action of these pollutants (Wang et al., 2020; Bhagat et al., 2020).

51 Plastics are widely used polymers, which came as a revolution in the past decades (Xu et al., 2017). In 52 2019, nearly 370 million tons of plastics were produced in the world and in Europe, plastics 53 production almost reached 58 million tons (PlasticsEurope, 2020). In Europe, $80 \%$ of the plastic 54 production resorts to six main polymers (PlasticsEurope, 2016): polypropylene (PP), high and lowdensity polyethylene (HDPE and LDPE), polyvinyl chloride (PVC), polyurethane (PUR), polyethylene terephthalate (PET) and polystyrene (PS). It is estimated that rivers carry between $70 \%$ and $80 \%$ of plastic waste, most of which ends up in oceans (Horton et al., 2017). Through wave activities, UV degradation and physical abrasion, larger plastic pieces in the marine environment are fragmented, resulting in producing MPs and nanoplastics (NPs) (Born \& Schüttrumpf, 2019; Díaz-Mendoza et al., 2020). MPs are plastic particles ranging from $1 \mu \mathrm{m}$ to $5 \mathrm{~mm}$ (Cole et al., 2011; Wagner et al., 2014).

61 MPs ingestion was observed in numerous aquatic species, notably in filter-feeding bivalves at different life stages (Rist et al., 2019; Ward et al., 2019; Betsill et al., 2019; Bringer et al., 2020b). It can cause several harmful effects at the physiological and tissue levels, affecting the growth and reproduction of bivalves (Lee et al., 2013; Sussarellu et al., 2016; Lo and Chan, 2018), as well as 

physical injuries (Gall \& Thompson, 2015) and reduced eating behavior (Cole et al., 2015). At the individual level, this can lead to the depletion of energy reserves (Wright et al., 2013 and Xu et al., 2017), larval development leading to delays and malformations (Tallec et al., 2018), and swimming activity (Bringer et al., 2020a). Toxic effects are mainly observed using high laboratory exposures (and not in situ) compared to environmental concentrations reported in the literature (Paul-Pont et al., 2018). The environmental concentrations mainly consider size classes of MP > $333 \mu \mathrm{m}$ (Song et al., 2015; Zhao et al., 2014; Baldwin et al., 2016) and therefore contain a significant bias, with respect to the small sizes used in the laboratory. Environmental concentrations ranging from 0.002 to $0.5 \mathrm{mg}$ MP. $L^{-1}$ have been detected in surface water in different areas of the world (Eriksen et al., 2013; Enders et al., 2015).

Chlortoluron that belongs to substituted urea family is one of the most commonly used herbicides in wheat and barley crops. Chlortoluron inhibits photosynthesis and affects phytoplankton (Valiente Moro et al., 2012). In 2017, a maximum value of $0.18 \mu \mathrm{g} \cdot \mathrm{L}^{-1}$ was detected at the mouth of a river (surface water) flowing into the Pertuis Charentais (Leonard, 2017). A concentration of $0.14 \mu \mathrm{g} \cdot \mathrm{L}^{-1}$ of chlortoluron was detected in 2018, at the mouth of the Charente (Pertuis Charentais), close to oyster farms (Action program, 2018). The herbicide family has already been studied on oysters, showing effects at the early stages of development on survival and development (Mottier et al., 2013; Gamain et al., 2017; Behrens et al., 2016; Mai et al., 2013), during gametogenesis with genotoxic effects (Akcha et al., 2020), as well as by modulating molecular and biochemical parameters (Lee et al., 2017).

The valve activity on the oyster was measured using an HFNI (High Frequency Non-Invasive) valvometer biosensor (Andrade et al., 2016). This biosensor has made possible to monitor behavioural responses of bivalves when exposed to stress events, such as, contaminants. Assessing the valve activity behaviour through an HFNI valvometer has already been used to study contaminants, including traces of metals (Tran et al., 2004a, 2007), radionuclides (Tran et al., 2004b, 
valvometric behavioral study, under laboratory conditions, has been carried out to assess the consequences of exposure to pesticides and MPs. However, in recent years, several articles have underlined the relevance of modelling and analysing the behaviour of marine animals under experimental conditions mimicking environmental conditions (Mat et al., 2014; Ahmed et al., 2015). In the present study, under controlled conditions and to characterize the behaviour of the oyster valve, three parameters were recorded: VMC, VOA and VOD. In addition, a chronobiological analysis of the daily rhythm of the valve was carried out as well as a measurement of the daily growth. The aim of this study was to better understand the potentially disrupting effects of emerging contaminants (MPs and pesticides) alone or in cocktail on the daily growth and the valve activity of Pacific juveniles oysters (C. gigas).

\section{Material and Methods}

\subsection{Individuals and acclimatization}

Pacific oysters, Crassostrea gigas (Bayne et al., 2019; Bayne et al., 2017), were kindly provided by a hatchery ( ${ }^{\mathrm{TM}}$ France Naissain, France). This experiment was conducted on 12-month-old juvenile oysters $(59.5 \pm 1.1 \mathrm{~mm}, 22.6 \pm 1 \mathrm{~g}$ total mass) during autumn season (after the period of gametogenesis and fertilization). Four homogenous groups of diploid oysters ( $n=8 /$ condition) were chosen. Each group was distributed in a $37.5 \mathrm{~L}$ tank. Each tank was continuously filled with oxygenated seawater coming from a large buffer tank. For the experiment, oysters were acclimated for 7 days in UV-treated running $\left(78.3\right.$ L. $\left.\mathrm{h}^{-1}\right)$ seawater before being exposed to pollutants for 24 days. Seawater was taken from the Pertuis Breton (South-West, France), which is directly connected to the experimental area, and filtered using a $50 \mu \mathrm{m}$ and $10 \mu \mathrm{m}$ membrane in order to eliminate debris. Filtered seawater (FSW) was used for experimental exposure tanks. The FSW temperature in tanks was of $16.8 \pm 0.4{ }^{\circ} \mathrm{C}$ and the salinity of $35.7 \pm 0.2 \%$. The temperature value and salinity were daily measured. Throughout the experiment, nitrates, nitrites, chlorine and $\mathrm{pH}(7.3 \pm 1.0)$ were regularly 
117 measured to ensure consistency. A continuous bubbling and a brewing system were set up.

118 Throughout the duration of the experiment, a natural photoperiod was established. In addition, the

119 oysters were nourished thanks to the natural presence of phytoplankton in the seawater used.

120 During the acclimatization and experimental periods, no mortality events were recorded.

121 Nevertheless, failures of the valvometric signal recording, due to an electrical leak at electrodes level

122 during the study, reduced the number of oysters studied to respectively $n=7$ in the control, $n=6$ in

123 the chlortoluron, $n=8$ in the MP and $n=5$ under cocktail conditions.

124

\subsection{Experimental procedure}

126

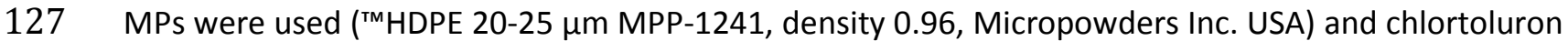
128 ('MPestanal, analytical standard, 45400-250MG-R reference) was purchased from Sigma-Aldrich

129 Chemical (St. Quentin Fallavier, France). The solutions containing MPs and chlortoluron were 130 prepared beforehand in test glass tubes. Stock solutions, prepared in pure Mili-Q-water, showed a

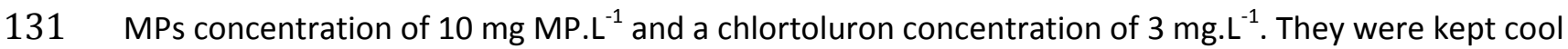
132 in the dark in order to prevent bacterial growth. The stored solutions were then diluted in FSW to

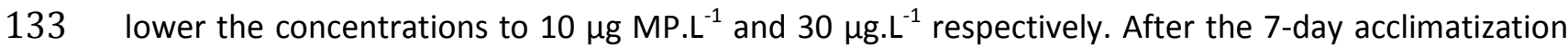
134 period, the pollutants are added to the experimental system, in the buffer tanks. Every two days, 30 $135 \%$ of the FSW in the buffer tank was renewed, for the well-health of the oysters. Upstream, FSW 136 were stored in separate tanks, with the tested pollutants, at a temperature similar to that of tanks 137 containing oysters. They were used to supply the buffer tanks during the renewal of FSW. Water 138 stirrers have been installed in each buffer tanks in order to homogenize the plastic microparticles as 139 much as possible in the seawater. In addition, the cytometric analyzes made it possible to determine 140 a certain homogeneity in the exposure tanks. Polystyrene foams protected tanks and equipment to 141 reduce vibrations from electrical equipment. In addition, capacitance chambers were installed to 
142 reduce vibrations from the air pipes bringing oxygen into FSW, along with behavioral analyzes (Fig.

143 S1).

2.3 HFNI valvometry analysis

147 To assess the pollutant impact (MPs and chlortoluron) on the oyster's valve behaviour, the valve

148 activity was recorded using a High Frequency Non-Invasive (HFNI) valvometer. The oysters were 149 equipped with light electromagnetic electrodes coated in resin $(\approx 1 \mathrm{~g})$, which were glued at the same

150 spot on both shells. The electrodes were attached to free covered stranded copper wires (diameter:

$1510.98 \mathrm{~mm}$, length: $120 \mathrm{~cm}$ ), sending data to a device. The induced voltage, measured by biosensors,

152 varied according to the distance between the electromagnetic electrodes. For each oyster, a 153 measure was taken every 4.8 sec., i.e. 18000 data/oyster/day. For more details, see Tran et al. 154 (2015) and Andrade et al. (2016). Bivalve behaviour was monitored 24/24 hours and 7/7 days (Tran et al., 2004a and Haberkorn et al., 2011). The biosensor used consists of very sensitive electrodes, resulting in minimal experimental constraints. The valve activity was recorded non-stop, both for the 7-day acclimatisation and the 24-day experimental periods. Then, the data were analysed using the LabView 8.6 software ( ${ }^{\mathrm{TM}}$ National Instruments, Austin, TX, USA).

160 Three behavioural parameters were assessed: daily and hourly VMC, VOA and VOD. Micro-closures

161 (VMC) designate partial and rapid closures followed by a re-opening of the valves. A VOA equal to $162100 \%$ and $0 \%$ meant that the valves were opened at maximal and minimal amplitudes, respectively, 163 during the studied duration. Finally, A VOD equal to $100 \%$ and $0 \%$ meant that the valves were 164 opened or closed, respectively, during the studied duration. Mean daily VMC, VOA and VOD were the 165 average results of the hourly values recorded for each oyster. The HFNI biosensor enabled to 166 individually measure the daily growth of shells by calculating the minimal distance between the 167 electrodes when the oyster valves were closed. For instance, in bivalve molluscs, calcification 
appears at the shell internal surface. Thus, the cumulative daily shell length growth was calculated as

169 indicated: minimal distance between electrodes (day (n) - day (1)) x $100 \%(n / 24)$, n representing the 170 number of the day. To obtain the actual shell length growth, manual measurements (digital caliper, \pm $1710.1 \mathrm{~mm}$ ) were performed at the start $\left(D_{0}\right)$ and at the end $\left(D_{24}\right)$ of the experiment. The difference in $172 \mathrm{~mm}$ equals $100 \%$ growth. Growth rates have been measured using the HFNI valvometer based on 173 the fact that calcification in bivalves occurs in the mantle cavity, all over the shell's internal structure 174 (Figure 4). When daily growth layers are deposited, the minimum distance between the electrodes 175 glued to the shells increases providing a good proxy of growth (Schwartzmann et al., 2011; Berge et 176 al., 2015).

177 To study the daily biological rhythm ( $\tau=24 \mathrm{~h}$ ) of the valve activity, a statistical chronobiological 178 analysis was conducted using the software Time Series Analysis Seriel Cosinor 6.3 179 (http://www.euroestech.com). Several steps were required to validate a significant biological rhythm 180 (Gouthiere et al., 2005). The first step included verifying the data quality of biological and physical 181 phenomena. The absence of random distribution in data was assessed using an autocorrelation diagram, whereas the absence of a stationary phenomenon was calculated with a partial autocorrelation function (Box et al., 2015). The second step involved searching significant periodicity $(p=0.95)$, using the Lomb and Scargle periodogram (Scargle, 1982). The third step added a modelling and statistical validation using the Cosinor model, which is a cosine function included in a regression model (Nelson et al., 1979). Two tests validated the model and, thus, the existence of a biological rhythm. The elliptic test (Bingham et al., 1982) had to be rejected, leading to a probability of null 188 amplitude hypothesis of $<0.05$. When conditions were met, a chronobiometric parameter computed 189 the Percent Rhythm (PR, \%), which is the percentage of cyclic behaviour determined by the Cosinor 190 model. 
194 Chlortoluron and MPs concentrations were measured twice: on day 5 ( $D_{5}, 5$ days after the start of 195 the experiment) and day $24\left(D_{24}\right.$, the last day of the experiment). Water samples ( $V=100$ $196 \mathrm{~mL} /$ replicate with $\mathrm{n}=3$ replicates) and oyster tissues ( $\mathrm{n}=7 /$ condition) exposed to both chlortoluron 197 and the cocktail solution were assayed using the QuEChERS method (Quick Easy Cheap Efficient 198 Rugged and Safe, Anastassiades et al., 2003) and the SBSE analysis (Stir Bar Sorptive Extraction, 199 Baltussen et al., 1999) (Pfannkoch et al., 2010 and from the AOAC 2007.01 method of Lehotay, 200 2007).

201 To analyse the oyster tissue and determine chlortoluron concentrations, $3 \mathrm{~g}$ of oyster tissue was 202 spiked with an internal standard solution. Milli-Q water was added to the solution to reach $15 \mathrm{~g}$. 203 After being vortexed once, samples were added with $15 \mathrm{ml}$ of acetonitrile (Pestinorm, VWR 204 Chemicals), before being vortexed a second time (1 $\mathrm{min}, 160 \mathrm{rpm}$ ). Then, $6 \mathrm{~g}$ of magnesium sulphate 205 (anhydrous, BioReagent, Sigma-Aldrich) and $1.5 \mathrm{~g}$ of sodium acetate (anhydrous, >99 \%, Sigma206 Aldrich) were added to the samples, which were then vortexed again (10 min, $250 \mathrm{rpm}$ ) and 207 centrifuged $\left(5 \mathrm{~min}, 4700 \mathrm{rpm}, 5^{\circ} \mathrm{C}\right)$. Two phases were formed and supernatant containing the 208 organic phase with acetonitrile was sampled. Then, $10 \mathrm{~mL}$ of the supernatant were collected in the 209 previous step and were taken and placed in a $125 \mathrm{~mL}$ flask, where $40 \mathrm{ml}$ of sodium carbonate $(0.1 \mathrm{M}$, $210 \geq 99.7 \%$, Sigma-Aldrich) was added. A Twister (magnetic stir bar coated with polydiméthylsiloxane) 211 was inserted into the bottle. SBSE extraction was performed ( $16 \mathrm{~h}, 700 \mathrm{rpm})$, in the dark). After the 212 completion of the extraction, the bars were rinsed off with Milli-Q water before being dried on a 213 fabric.

214 To analyse the chlortoluron seawater exposure samples, $10 \mathrm{~mL}$ of methanol (Pestinorm, VWR 215 Chemicals) was put in a bottle containing the internal standard solution. $100 \mathrm{~mL}$ of seawater and a 216 Twister were then added. Protected from light, the solution was stirred for 16 hours at $700 \mathrm{rpm}$.

217 Chlortoluron was quantified by gas chromatography (HP 7890N equipped with a Combipal MPS2 218 multifunction injection system, $300{ }^{\circ} \mathrm{C}$, Gerstel, Switzerland) and mass spectrometry (GC/MS), 219 coupled with a TDU (Thermal Desorption Unit, Gerstel: $50^{\circ} \mathrm{C}(0.5 \mathrm{~min})$ to $280^{\circ} \mathrm{C}(6 \mathrm{~min})$ at $\left.15^{\circ} \mathrm{C} / \mathrm{min}\right)$ 
and a temperature-programmed injector (Cooled Injection System, Gerstel: $-10{ }^{\circ} \mathrm{C}$ (0.05 min) to 300

$221{ }^{\circ} \mathrm{C}(10 \mathrm{~min})$ at $\left.12{ }^{\circ} \mathrm{C} / \mathrm{s}\right)$. The temperature was programmed from $70^{\circ} \mathrm{C}(5 \mathrm{~min})$ to $150{ }^{\circ} \mathrm{C}$ increasing by $22220^{\circ} \mathrm{C} / \mathrm{min}$, then to $320^{\circ} \mathrm{C}(5 \mathrm{~min})$ increasing by $7{ }^{\circ} \mathrm{C} / \mathrm{min}$. The carrier gas, helium, was at constant 223 flow rate ( $1 \mathrm{~mL} / \mathrm{min})$. The capillary column was a 5-ms RXi (Restek, Bellefonte, USA): $30 \mathrm{~m} \times 0.25 \mathrm{~mm}$ 224 ID $\times 0.25 \mu \mathrm{m}$ (film thickness) column. Through tandem mass spectrometry (Agilent 7000 Triple Quad), 225 a chromatograph and a detector were coupled together. The quantitative analysis of chlortoluron was performed in MRM mode by internal calibration. Two transitions for each compound were set up: the first to quantify the molecules and the second to confirm their nature. The second step defined the nature by calculating the qualifier/quantifier ratio and comparing them to the reference values of pure compounds. The acquisition frequency of each fragment was of 2 cycles/s.

Due to the small sizes of particles $(20-25 \mu \mathrm{m})$, the MPs analysis in oyster tissues was not performed. According to the protocol described in Bringer et al. (2020a \& 2020b), flow cytometer (Attune Acoustic Focusing Cytometer) enabled a quantitative analysis of MPs in the $10 \mu \mathrm{g}$ MP. $\mathrm{L}^{-1}$ condition. 2 $m L$ samples were prepared with the MPs solution ( $n=8 /$ condition). The samples were vortexed (StarLab Vortex IR, 12,000 rpm for $20 \mathrm{~s}$ ) before being transferred into the cytometer to homogenise the solution. $300 \mathrm{~mL}$ were taken to carry out a flow cytometry analysis. Calibration was conducted to reach an analysis rate of $500 \mathrm{~mL} \cdot \mathrm{min}^{-1}$ and a saturation of maximum 10,000 particles detected. The blank obtained enabled to remove background particles (naturally present in seawater). Using seawater filtered at $0.2 \mu \mathrm{m}$, a first calibration step was conducted to select the $<200$-time detected particles.

\subsection{Statistics}

244 All data were expressed as means \pm standard error of the mean (SEM). Treatment differences were 245 determined using a one-way analysis of variance (ANOVA), when both criteria of homogeneity of 
246 variance (Levene's test) and normality of distribution (Shapiro-Wilk) were met. When these

247 requirements were not met, a statistical analysis was performed using the non-parametric Kruskal-

248 Wallis test, followed by the Nemenyi Post-hoc test for pair comparisons. Statistical comparisons were 249 made on the means of each parameter according to the exposure conditions. Significant difference 250 was accepted when $p$-value $<0.05$. The statistical analysis was conducted using R.

3. Results

\subsection{Pollutant exposure}

It is noted, that no significant difference was observed concerning the assays carried out for 256 chlortoluron (FSW and total tissues), nor for MP (FSW). Chlortoluton concentrations were determined in exposure waters (Table 1.a). Under control, water contamination increased over time. On $\mathrm{D}_{24}$ (condition chlortoluron vs cocktail), an increase in the concentration of chlortoluron was noted. The concentration of chlortoluron in the cocktail condition was slightly higher than for the condition of chlortoluron alone (at $D_{5}$ and $D_{24}$ ). In both cases, the measured concentrations were well

261 above the theoretical concentration of $30 \mu \mathrm{g} \cdot \mathrm{L}^{-1}$. The concentrations of chlortoluron measured on the

262 soft body of the oyster are shown in Table 1.a. No trace of herbicide was detected in control 263 individuals. While in exposed individuals, tissue concentrations of chlortoluron were measured at 264 both sampling times $D_{5}$ and $D_{24}$.

266 The concentrations of MP in FSW (Table 1.b) were above the desired theoretical concentration of 10 $267 \mu \mathrm{g}$ of MP.L.-1. The approximate actual concentrations calculated in this study were determined using 268 additional data from a previous study (Bringer et al., 2020a), which used and tested the same commercial MP (HDPE, 20-25 $\mu \mathrm{m}$ ), at different concentrations. The additional data allowed for calibration and validation of the current results. The concentrations of MP were stable over time $\left(D_{5}\right.$ 
271 and $\mathrm{D}_{24}$ ) and similar between the exposure conditions (MP alone vs cocktail). In addition, an analysis

272 of the particles in the control FSW was performed and no MP particles were detected.

273

274 Table 1. (a) Theoretical and measured chlortoluron (herbicide) concentrations in oyster tissues (dry weight)

275 and seawater for three conditions: control, chlortoluron and cocktail (MPs + chlortoluron). Values are mean \pm

276 SEM for $n=7 /$ condition for oyster tissues and $n=3 /$ condition for water samples. (b) Theoretical, measured MPs

277 and approximate concentrations concentrations in three conditions: control $(n=12)$, MPs $(n=8)$ and cocktail

278 (MPs + chlortoluron, $n=8$ ). Values are mean \pm SEM.

$279 \quad$ a

\begin{tabular}{ccccc}
\hline Conditions & Samples time & $\begin{array}{c}\text { Theoretical } \\
\left(\mu \mathrm{g} . \mathrm{L}^{-1}\right)\end{array}$ & $\begin{array}{c}\text { Oyster tissues } \\
\left(\mathrm{ng} . \mathrm{g}^{-1}\right)\end{array}$ & $\begin{array}{c}\text { Water exposure } \\
\left(\mu \mathrm{g} . \mathrm{L}^{-1}\right)\end{array}$ \\
\hline \multirow{2}{*}{ control } & Day 5 & 0 & 0 & $0.06 \pm 0.0$ \\
& Day 24 & 0 & 0 & $1.5 \pm 0.9$ \\
\hline \multirow{2}{*}{ chlortoluron } & Day 5 & 30 & $226.9 \pm 69.5$ & $58.3 \pm 25.1$ \\
& Day 24 & 30 & $229.5 \pm 92.0$ & $85.5 \pm 17.0$ \\
\hline \multirow{2}{*}{ cocktail } & Day 5 & 30 & $366.0 \pm 132.7$ & $74.6 \pm 4.9$ \\
& Day 24 & 30 & $242.3 \pm 199.6$ & $96.6 \pm 25.8$ \\
\hline
\end{tabular}

280

b

\begin{tabular}{ccccc}
\hline Conditions & Samples time & $\begin{array}{c}\text { Theoritical } \\
\left(\mu \mathrm{g} \mathrm{MP.L^{-1 } )}\right.\end{array}$ & $\begin{array}{c}\text { Measured }\left(\mathrm{MP}_{\mathrm{mL}} \mathrm{m}^{-1}\right) \\
\mathbf{2 0 - 2 5} \boldsymbol{\mu m} \text { size }\end{array}$ & $\begin{array}{c}\text { Approximate concentrations } \\
\left(\mu \mathrm{g} \mathrm{MP.} \mathrm{L}^{-1}\right)\end{array}$ \\
\hline \multirow{2}{*}{ control } & Day 5 & 0 & 0 & 0 \\
& Day 24 & 0 & 0 & 0 \\
\hline \multirow{2}{*}{ MPs } & Day 5 & 10 & $93.9 \pm 31.2$ & 47 \\
& Day 24 & 10 & $111.7 \pm 11.5$ & 56 \\
\hline \multirow{2}{*}{ cocktail } & Day 5 & 10 & $124.4 \pm 30.3$ & 60 \\
& Day 24 & 10 & $107.6 \pm 49.3$ & 54 \\
\hline
\end{tabular}

\subsection{Valve activity of oysters}

\subsubsection{Valve Micro-Closures (VMC)}

285 The number of VMC per day and per individual is shown on Fig. 1a. Compared to the other conditions, the daily VMC in MPs over the 24-day experiment highlighted a significant increase $(p<$ 0.001). The mean VMC for MPs was 2.9 times higher than for the control condition (Fig. 1b). Fig. $1 \mathrm{~b}$ 


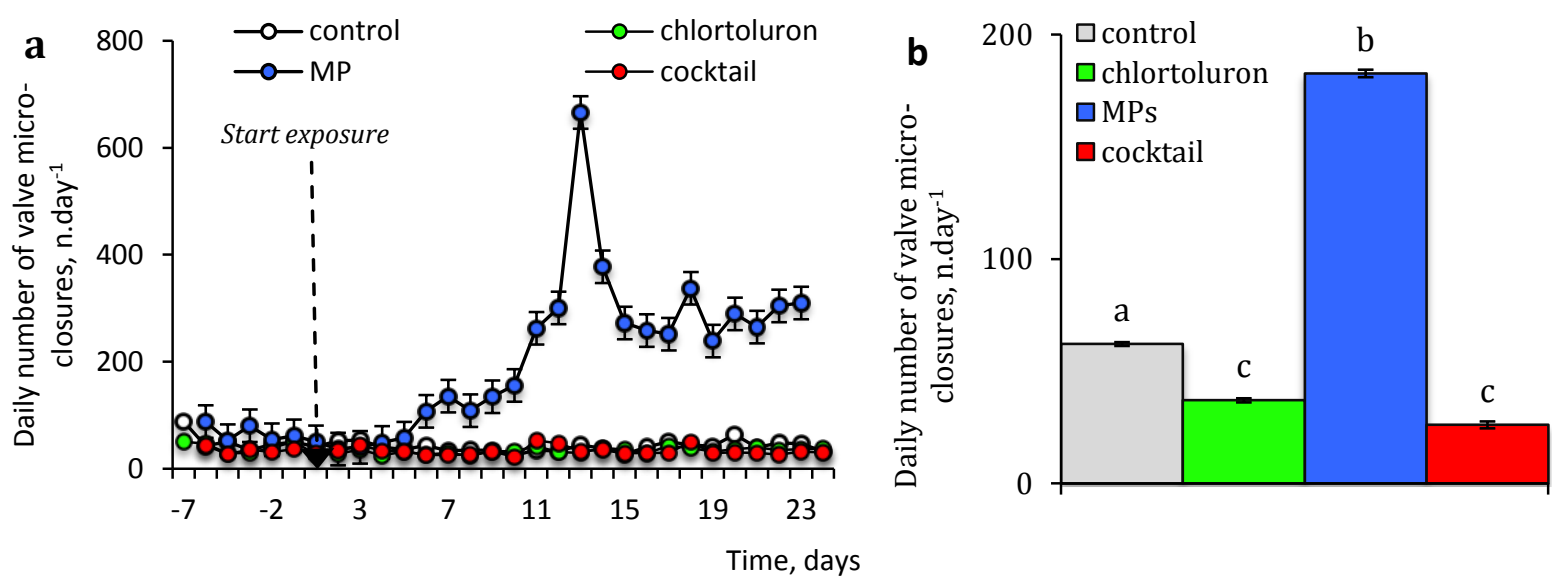

293 Fig. 1. (a) Daily VMC showing the 7-day acclimatisation and the 24-day exposure periods. (b) Histograms of 294 mean VCM \pm SEM for the 24-day exposure period. The different conditions are: control (white, $\mathrm{n}=7$ ), 295 chlortoluron alone (green, $n=6$ ), MPs alone (blue, $n=8$ ) and cocktail (red, $n=5)$. Different letters indicate 296 significant differences between concentrations $(p<0.05)$.

\subsubsection{Valve Opening Amplitude (VOA)}

In terms of VOA, the 24-day experiment underlined contrasting results between the MPs condition

301 and the two other conditions containing herbicides (Fig. 2a, b, c). Although the VOA was similar for 302 the MPs and control conditions (with no significant differences), it was significantly higher in 303 chlortoluron and cocktail conditions compared to control (both $p<0.001$ )

304 Over the entire experiment, the mean VOA displayed major differences between the four conditions $305(p<0.001)$. Compared to the control condition, a significant increase in mean VOA of $18.2 \%$ and 22.3 $306 \%$ were respectively noted for the chlortoluron alone and cocktail conditions (Fig. 2d). 

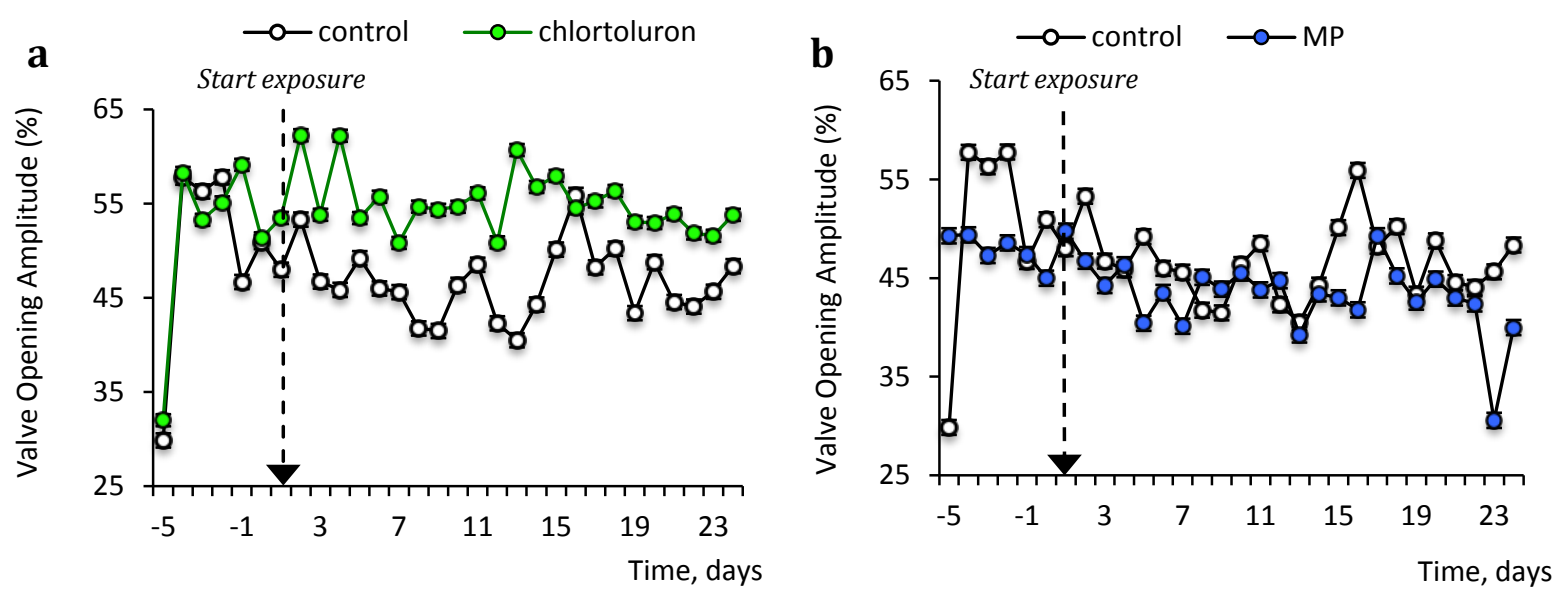

308
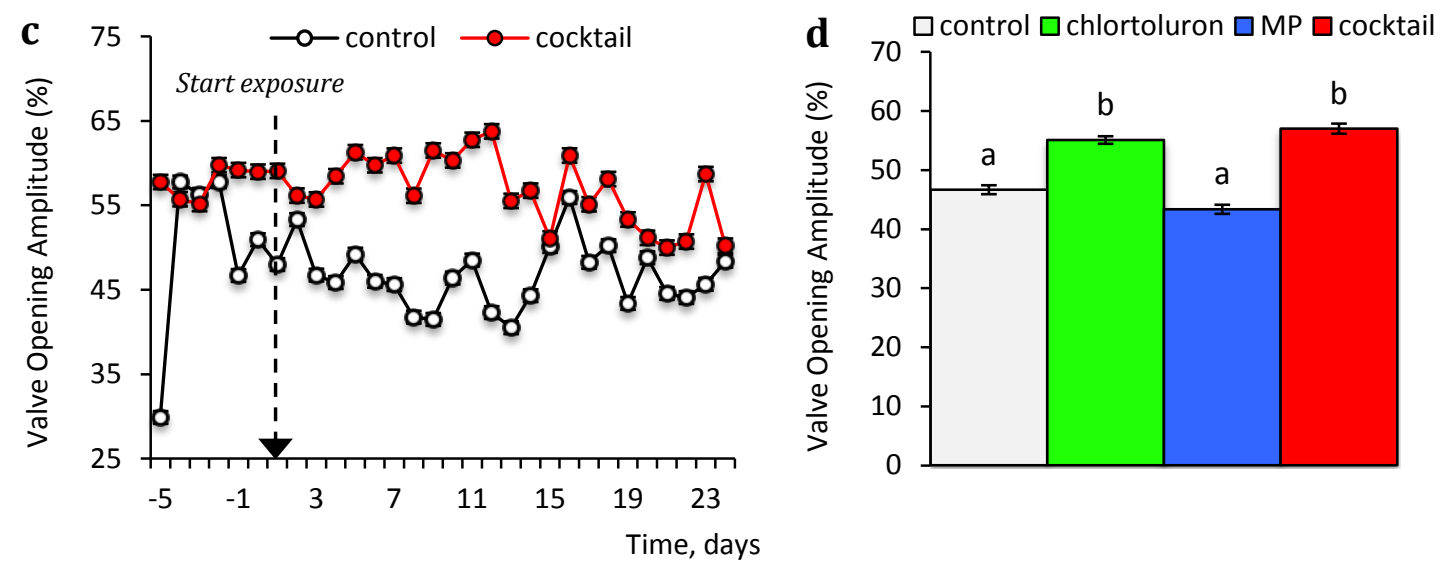

310 Fig. 2. Valve Opening Amplitude (VOA) in percentage for each condition: (a) chlortoluron alone (green), (b) MPs 311 alone (blue) and (c) cocktail (red), in comparison with the control condition (white). (d) Histograms of VOA (\%)

312 for the entire exposure and all conditions. Values are mean \pm SEM for control $(n=7)$, chlortoluron $(n=6)$, MPs

$313(n=8)$ and cocktail $(n=5)$ conditions. Different letters indicate significant differences between concentrations $314(p<0.05)$.

\subsubsection{Valve Opening Duration (VOD)}

Over the 24-day experiment (Fig. 3 a, b, c), the VOD for both the chlortoluron and cocktail conditions remained unchanged. In contrast, the VOD for the MPs condition significantly decreased compared to the control condition. Indeed, over the entire experiment, the mean VOD highlighted a significant decrease $(p<0.001)$ of $5.1 \%$ for the MPs condition, compared to the control one (Fig. 3d). 

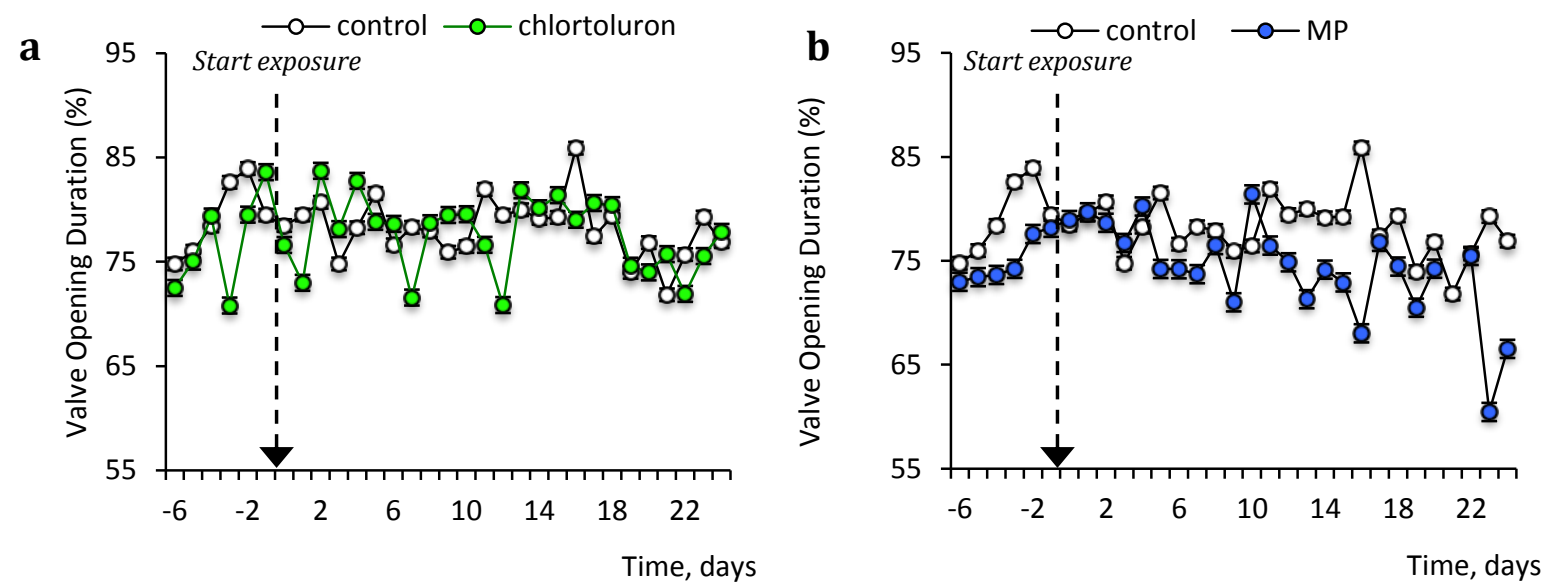

323
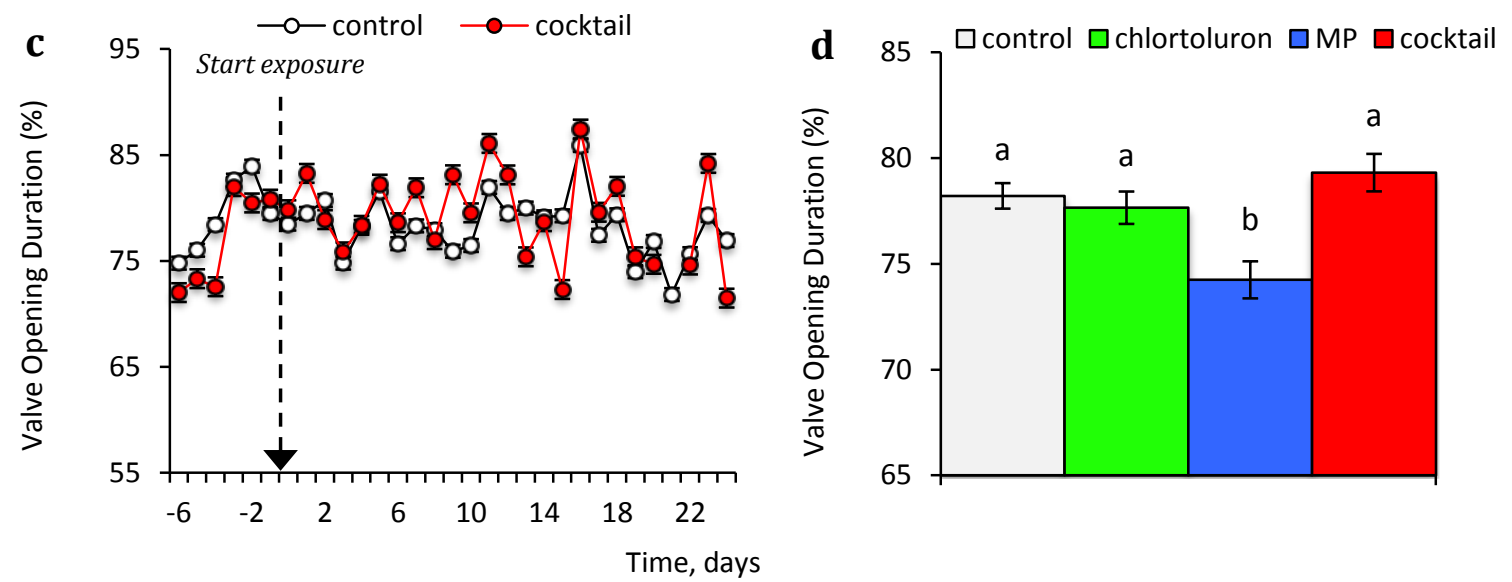

Fig. 3. Valve Opening Duration (VOD) in percentage for each condition: (a) chlortoluron alone (green), (b) MPs alone (blue) and (c) cocktail (red), in comparison with the control condition (white). (d) Histograms of VOA (\%) for the entire exposure and all conditions. Values are mean \pm SEM for control $(n=7)$, chlortoluron $(n=6)$, MPs

$328(n=8)$ and cocktail $(n=5)$ conditions. Different letters indicate significant differences between concentrations $329(p<0.05)$.

\subsubsection{Chronobiological analysis}

333 Through a statistical chronobiological approach, a daily rhythm analysis was performed using the

334 Cosinor method. When comparing the three conditions to the control one, no significant disruption of VOA rhythm was observed. Figure S2 displays for each condition, the spectral analysis of the valve activity (Lomb and Scargle periodogramm). It highlighted a significant periodicity in the valve 
338 (chlortoluron); $23.9 \pm 0.1$ (MPs); $23.9 \pm 0.1 \mathrm{~h}$ (cocktail). Periodicities were observed using the Cosinor 339 model, which validated the presence of a daily rhythm for all conditions $(p<0.0001$ for all 340 conditions). The percent rhythms (PR) between conditions were quite close, except for chlortoluron, 341 which had a lower PR. PR were $46.4 \%$ (control), $32.3 \%$ (chlortoluron), $42.8 \%$ (MPs) and $45 \%$ 342 (cocktail).

\subsubsection{Shell Growth}

346 The Fig. 4a displays the cumulative daily shell growth, monitored for 24 days. No significant 347 difference was calculated between the control and chlortoluron conditions $(p=0.07)$ but this $p$-value 348 is close to the statistical significance and, therefore express a trend. In contrast, over 24 days, oysters exposed to the MPs and cocktail conditions underlined a lower shell growth. Indeed, after the 24-day period, the mean shell length growth for the MPs and cocktail conditions respectively was reduced of $35150.4 \%(p<0.0001)$ and $42.7 \%(p=0.021)$, in comparison with the control one (Fig. $4 \mathrm{~b})$. The oyster shell growth observed for the MPs and cocktail conditions were also lower than observed for the exposure to chlortoluron alone.
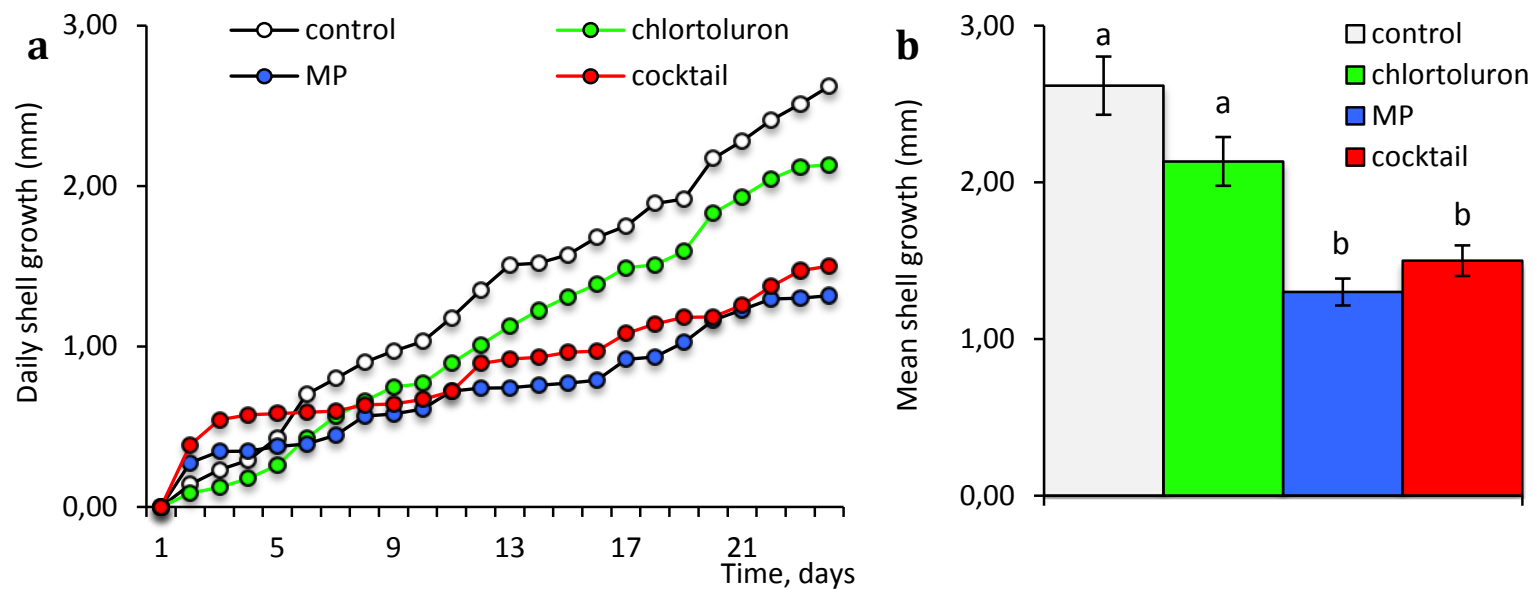

356 Fig. 4. (a) Daily shell length growth monitored for all conditions (mm). (b) After the completion of the 24-day experiment, histograms displaying the mean shell growth $(\mathrm{mm})$ of the oysters equipped with electrodes. The 
different conditions are: control (no pollutants, white), chlortoluron alone (green), MPs alone (blue) and cocktail (red). Values are mean \pm SEM for control $(n=7)$, chlortoluron $(n=6)$, MPs $(n=8)$ and cocktail $(n=5)$ conditions. Different letters indicate significant differences between concentrations $(p<0.05)$.

\subsubsection{Summary of the main results}

363

364 The actual concentrations measured on $\mathrm{D}_{24}$, in the FSW exposure (for MP and chlortoluron alone and cocktail), are presented in Table 2, as well as in the remainder of this present study. In our work, the analysis validated the existence of a daily rhythm for all tested conditions. No significant differences in chronobiological rhythms were noted between the four conditions tested. Regarding the behavioural parameters, our results suggest that, when exposed to chlortoluron, the oyster valve activity was significantly disrupted (Table 2 ). Indeed, in comparison with the control condition, a

370 decrease in the number of VMC and an increase in VOA were noted. In terms of MPs exposure, a

371 significant increase in VMC, and a decrease in VOD and growth were observed. Concerning the 372 cocktail condition, a decrease in VMC and growth, and an increase in VOA were highlighted. 373 Depending on the exposure conditions, the valve behaviour in oysters responded differently.

Table 2. Summary of the effects on the Pacific oyster valve activity induced after a 24-day exposure to chlortoluron alone $\left(85 \mu \mathrm{g} . \mathrm{L}^{-1}\right), 20-25 \mu \mathrm{m}$ HDPE MPs alone (112 MP. $\mathrm{mL}^{-1}$ ) and a combination of both (cocktail,

$37797 \mu \mathrm{g} \cdot \mathrm{L}^{-1}$ of chlortoluron + $108 \mathrm{MP} \cdot \mathrm{mL}^{-1}$ ). Measured parameters are VMC (Valve Micro-Closures), VOA (Valve 378 Opening Amplitude), VOD (Valve Opening Duration), daily rhythm (chronobiological analysis) and shell growth (

$379 \uparrow$ : significant increase compared to the control condition, $\downarrow$ : significant decrease compared to the control condition and - : absence of significant effects compared to the control condition). 


\begin{tabular}{cccccc}
\hline Conditions & VMC & VOA & VOD & Daily rhythm & Shell growth \\
\hline Chlortoluron alone & $\downarrow$ & $\uparrow$ & - & - & - \\
\hline MPs alone & $\uparrow$ & - & $\downarrow$ & - & $\downarrow$ \\
\hline Cocktail & $\downarrow$ & $\uparrow$ & - & - & $\downarrow$ \\
\hline
\end{tabular}

\section{Discussion}

\subsection{Experimental concentrations versus natural environment}

In our FSW exposures, concentrations between 58 and $96 \mu \mathrm{g} \cdot \mathrm{L}^{-1}$ were measured The study by

Valiente Moro et al. (2012) reported an $\mathrm{IC}_{50}$ (half-maximum inhibitory concentration) of $50 \mu \mathrm{g} \cdot \mathrm{L}^{-1}$ on the freshwater phytoplankton Ankistrodesmus fusiformis. Although this concentration is higher than those commonly found in the Pertuis Charentais, it is quite close to the maximum concentrations detected in some European rivers. Indeed, concentrations of herbicide (chlortoluron in particular) of

$39120 \mu \mathrm{g} \cdot \mathrm{L}^{-1}$ and more (Beitz et al., 1994) were determined. For herbicide exposure, control FSW 392 highlighted a slight contamination to chlortoluron. Being volatile, it could easily evaporate in the 393 atmosphere and contaminate the other tanks (Ineris, 2013). Nevertheless, the concentrations of 394 chlortoluron measured in the control FSW samples were satisfactory, to validate the study. An 395 increase of chlortoluron concentrations was observed between the start $\left(D_{5}\right)$ and the end of the 396 experiment $\left(D_{24}\right)$. This increase could be explained by the initial presence of chlortoluron in natural 397 seawater (0.14 $\mu \mathrm{g} \cdot \mathrm{L}^{-1}$ in 2018 , Action program, 2018) and regular water changes during the 398 experiment. In this present study, the theoretical concentration of HDPE MPs $(20-25 \mu \mathrm{m})$ was set at

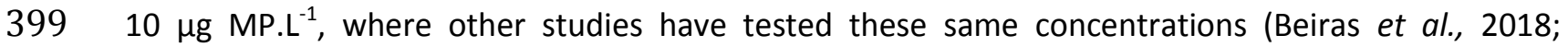
400 Constant, 2018; Lei et al., 2018 and Dris et al., 2016). To assess MPs/NPs in water, flow cytometry 401 was performed, as used in some studies (Long et al., 2017; Caputo et al., 2021; Kaile et al., 2020).

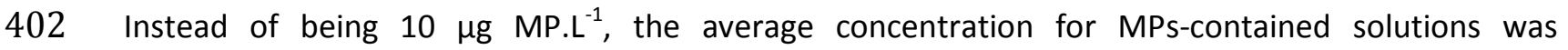

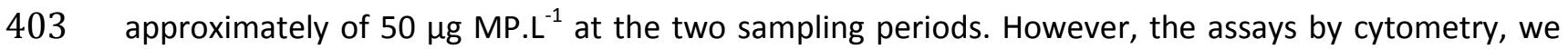


confirm contents between 93.9 and $107.6 \mathrm{MP} . \mathrm{mL}^{-1}$. The highest environmental concentration of MP

405 detected in Artic sea ice cores is around $13.7 \mathrm{MP} \cdot \mathrm{mL}^{-1}$ (Peeken et al., 2018). However, the size classes

406 of MP detected in the natural environment are larger than MP tested in the laboratory (Paul-Pont et

407 al., 2018). Our present study could be defined as realistic in terms of size tested but not in terms of concentration. According to a study on the characterization of MP on the Atlantic coast, the majority of MP (64\%) were $<40 \mu \mathrm{m}$. In addition, about half (42\%) of them were PE (Enders et al., 2015). These results justify the use of HDPE-MP $(20-25 \mu \mathrm{m})$ in this study. In addition, some equipment used

411 in aquaculture for bivalves consists mainly of PE (Lusher et al., 2017 and Bringer et al., 2021). The

412 differences observed between the theoretical and measured MP concentrations could come from 413 the aggregation of MP (Alimi et al., 2018; Michels et al., 2018) on the walls of the exposure tanks. 414 Long et al. (2017) clearly showed that micro-PS may attach to glassware, form homo-aggregates and 415 hetero-aggregates. In addition, regular water changes, for the welfare of oysters, could also have 416 played a role in increasing theoretical concentrations.

\subsection{Behavioural responses of juveniles' oysters (C. gigas) to chlortoluron exposure}

Chlortoluron is a photosynthesis-disrupting herbicide, and more specifically as an inhibitor of 421 photosystem II (Faggiano et al., 2010). Phytoplankton communities have been shown to be very 422 sensitive to herbicides (Solomon et al., 1996). Indeed, effects on phytoplankton growth and 423 development have been observed (El-Sheekh et al., 1994), and could indirectly affect filter feeders such as oysters when they feed. Chlortoluron showed a significant decrease in VMC in number compared to condition control. An equivalent result has already been demonstrated for Mytilus galloprovincialis exposed to cypermethrin (insecticide) with a reduced the valve closure in a timedependent manner (Ayad et al., 2011). Higher VOA, at condition control, was also detected following 428 exposure to chlortoluron. An apparent increase in the rate of opening of the shell under 429 contamination with an herbicide (lenacil) was reported in an earlier study (Chmist et al., 2019). 
However, this parameter has been little studied in order to obtain relevant interpretations (Bae \&

431 Park, 2014). Chlortoluron may have a specific reducing effect on some distinctive phytoplankton

432 species important for the physiology, development and behaviour of oysters (Stachowski-Haberkorn

433 et al. 2008). Additional studies should be carried out in order to better understand the effect of this

434 herbicide on phytoplankton populations and on oyster nutrition. Moreover, combined effect of VMC

435 decrease and VOA increased may suggest that the herbicide lead to an apparent relaxed behaviour

436 of valve activity. Next investigations should focus on putative neurotoxic effects of chlortoluron on

437 oyster valve activity. Indeed, it would be of interest to study if the chlortoluron may block conduction

438 of action potential at the voltage-gated sodium channels level, which plays a crucial role in

439 membrane excitability in nerve cell, and lead to a decrease of neuro-muscular response. This

440 neurotoxic effect has already been shown for many neurotoxins produced by animals or plants, such

441 as saxitoxin and tetrodotoxin (Boulot et al., 2017).

4434.3 Behavioural responses of juveniles' oysters (C. gigas) to microplastics exposure

445 Oysters exposed to MP showed a higher number of VMC compared to the others conditions. VMC is

446 defined as a marker of stress in oysters (Tran et al., 2010). The presence of MP in the seawater, 447 which could be detected by oysters, can induce mechanical stress (Sow et al., 2011). The presence of 448 harmful substances could activate chemoreceptors on the edge of the oyster mantle or directly 449 affect the gills when the pollutants are in direct contact with the tissue of the pallial cavity, 450 responsible for the rapid increase in the frequency of VMC. According to the work of Castrec et al. 451 (2018), a similar hypothesis could be made, implying that the increase in the frequency of VMC is a 452 protective behavioral response to accelerate interval water turnover and minimize potential contacts 453 with MP, irritating the gills (Zhu et al., 2020). A significant decrease in VOD was also measured. 454 Likewise, a freshwater bivalve (Corbicula fluminea) had a behavioral closure reaction - as a protective 455 strategy - when exposed to a metallic contaminant (Tran et al., 2004a). The branchial cavities and the 
labial palps (Ward et al., 1998) determine the different modes of selection and sorting of particles,

457 which could slow down the filtration of nutrients of exposed oysters, affect their feeding activity,

458 their behaviour, and reduce their metabolism and their growth. Indeed, several studies have noted

459 that toxins and foreign bodies can modify the nutritional activity of oysters through behavioral

460 modifications (Tran et al., 2010; Haberkorn et al., 2010). Oysters exposed to MP grow more slowly

461 than control oysters. Some previous work has shown non-effects of MP on oysters during subchronic exposure (Green, 2016; Revel et al., 2020). However larger sizes of MP (103 $\mu \mathrm{m}$ and $300 \mu \mathrm{m})$ were tested contrary to this present study $(20-25 \mu \mathrm{m})$. The study by Gardon et al. (2018) showed a

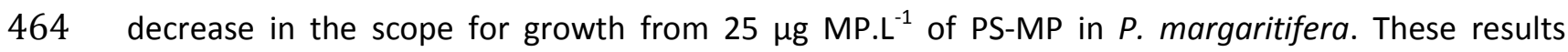
465 indicate that the exposed oysters must have drawn their energy from the reserves. In addition, the 466 assimilation of microalgae was disturbed by the presence of micro-PS, and the energy provided by 467 food intake was lower for exposed oysters (Gardon et al., 2018). In the study conducted by Thomas 468 et al. (2020), the condition index at the highest concentration (106 MP. $\mathrm{L}^{-1}$ ) decreased significantly 469 over time. The concentration tested is similar to our concentrations measured in MP exposure 470 waters.

475 For oysters exposed to the cocktail, results similar to the chlortoluron condition were noted, on VMC 476 and VOA. No effect on VOD was noted in contrast to its decrease for exposure to MP. Chlortoluron 477 and MP may have antagonistic effects. A previous study demonstrated antagonistic effects between $478 \mathrm{NP}$ and glyphosate on the microalgae Microcystis aeruginosa (Zhang et al., 2018). Combined 479 exposure to diclofop-methyl and silver nanoparticles has been shown to antagonize the growth 480 inhibition of $A$. Thaliana (Li et al., 2018). In our study, growth decreased under the cocktail condition 481 as for the MP condition. Studies have pointed out that MP can make hydrophobic organic chemicals 
482 bioavailable by acting as an absorption vector (Horton et al., 2018). However, our results do not

483 show significantly different effects for the cocktail, compared to MP and therefore we cannot

484 conclude on a potential vectorization of chlortoluron on MP. The results showed that the synergistic

485 effect of chlortoluron and MPs is not significant, compared to the contamination conditions alone.

486 Their common ecotoxic effects are affected by physical and chemical factors such as particle size,

487 color, composition, function (Yu et al., 2021). Due to their high filtration rate, marine bivalves, like

488 oysters, are particularly sensitive to chemical contamination, which can be a major source of stress

489 and behavioral alteration (Sokolova and Lannig, 2008; Islam and Tanaka, 2004).

491 5. Conclusions

492 On a larger scale, valvometric technology is a tool for monitoring water quality, using oysters as

493 biosensors (Ahmed et al., 2015). This study provided valuable data on the behavior of bivalves 494 exposed to pollutants potentially present in the marine environment. Exposure to chlortoluron had 495 little impact on their behavior and none on their growth. This study provided insight into the 496 evidence that MP could potentially affect the physiology and behavior of $C$. gigas. MPs tended to act 497 as stressors in bivalves, triggering urgent behavioral responses. In addition, MP could affect the 498 filtration capacity of bivalves (nutrient system) and, indirectly, their growth. The combination of the 499 two pollutants showed antagonistic responses to the conditions of contamination alone. Rarely used 500 in studies, valvometric technology is an innovative, integrated and comprehensive marker that helps 501 to understand the effects of environmental pollution. Future studies on the effects of MP on bivalves 502 could use HFNI valvometry, mimicking environmental conditions (e.g. size range, concentrations, 503 pollutant cocktail).

\section{Acknowledgements}


507 A. Bringer received a PhD grant (Comité Régional de la Conchyliculture de la Charente Maritime

508 CRC17) as well as financial support from the Région Nouvelle Aquitaine and Comité Départemental

509 de la Charente Maritime (CD17) to develop his research. The AQUAECOs project (Amélioration de la

510 QUAlité Environnementale sur les zones COnchylicoles des Pertuis Charentais), funded by a

511 partnership with CRC17, and the AFB (Agence Française de la Biodiversité, Parc naturel marin de

512 l'estuaire de la Gironde et de la mer des Pertuis) contributed financially to this study. The funding was

513 partly supported by the University of La Rochelle, the University of Bordeaux, the Centre National de

514 la Recherche Scientifique (France). The authors thank the France Naissain hatchery for providing the

515 oyster specimens as well as our collaborators for their work and help.

516

517

References

518

519

Action program, Coastal water quality in shellfish farming areas, Qualyse, CD17, 2018-2020 (accessed

520

October 2020).

521

522

Ahmed, H., Ushirobira, R., Efimov, D., Tran, D., \& Massabuau, J. C. (2015). Velocity estimation of

523 valve movement in oysters for water quality surveillance. IFAC-PapersOnLine, 48(11), 333-338.

524

525 Akcha, F., Barranger, A., \& Bachère, E. (2020). Genotoxic and epigenetic effects of diuron in the

526 Pacific oyster: in vitro evidence of interaction between DNA damage and DNA

527 methylation. Environmental Science and Pollution Research, 1-15.

528

529 Alimi, O. S., Farner Budarz, J., Hernandez, L. M., \& Tufenkji, N. (2018). Microplastics and nanoplastics

530 in aquatic environments: aggregation, deposition, and enhanced contaminant transport.

531 Environmental science \& technology, 52(4), 1704-1724. 
533 Andrade, H., Massabuau, J. C., Cochrane, S., Ciret, P., Tran, D., Sow, M., \& Camus, L. (2016). High

534 frequency non-invasive (HFNI) bio-sensors as a potential tool for marine monitoring and 535 assessments. Frontiers in Marine Science, 3, 187.

536

537 Ayad, M. A., Fdil, M. A., \& Mouabad, A. (2011). Effects of cypermethrin (pyrethroid insecticide) on 538 the valve activity behavior, byssal thread formation, and survival in air of the marine mussel Mytilus 539 galloprovincialis. Archives of environmental contamination and toxicology, 60(3), 462-470.

540

541 Bae, M. J., \& Park, Y. S. (2014). Biological early warning system based on the responses of aquatic 542 organisms to disturbances: a review. Science of the Total Environment, 466, 635-649.

544 Baldwin, A. K., Corsi, S. R., \& Mason, S. A. (2016). Plastic debris in 29 Great Lakes tributaries: relations 545 to watershed attributes and hydrology. Environmental Science \& Technology, 50(19), 10377-10385.

547 Bayne, B.L., Ahrens, M., Allen, S.K., D’auriac, M.A., Backeljau, T., Beninger, P., Bohn, R., Boudry, P., 548 Davis, J., Green, T., Guo, X., Hedgecock, D., Ibarra, A., Kingsley- Smith, P., Krause, M., Langdon, C., 549 Lape_gue, S., Li, C., Manahan, D., Mann, R., Perez-Paralle, L., Powell, E.N., Rawson, P.D., Speiser, D., 550 Sanchez, J.-L., Shumway, S., Wang, H., 2017. The proposed dropping of the genus Crassostrea for all 551 pacific cupped oysters and its replacement by a new genus Magallana: a dissenting view. J. Shellfish 552 Res. $36(3), 545 \mathrm{e} 548$.

554 Bayne, B., d'Auriac, M.A., Backeljau, T., Beninger, P., Boudry, P., Carnegie, R., Langdon, C., 2019. A 555 scientific name for Pacific oysters. Aquaculture 499, 373. 
558 of the herbicide diuron and its metabolites in early life stages of Crassostrea gigas: implication of

559 reactive oxygen species production. Aquatic Toxicology, 175, 249-259.

560

561 Beiras, R., Bellas, J., Cachot, J., Cormier, B., Coussin, X., Engwall, M., Gambardella, C., Garaventa, F.,

562 Keiter, S., Le Bihanic, F., Lopez-Ibanez, S., Piazza, V., Rial, D., Tato, T., Vidal-Linan, L. (2018). Ingestion

563 and contact with polyethylene microplastics does not cause acute toxicity on marine zooplankton.

564 Journal of Hazardous Materials, 360, 452-460.

565

566 Beitz, H., Schmidt, H., \& Herzel, F. (1994). Occurrence, toxicological and ecotoxicological significance

567 of pesticides in groundwater and surface water. In Pesticides in ground and surface water (pp. 1-56).

568 Springer, Berlin, Heidelberg.

569

570 Berge, J., Daase, M., Renaud, P. E., Ambrose, W. G. Jr., Darnis, G., Last, K. S., et al. (2015). Unexpected

571 levels of biological activity during the polar night offer new perspectives on a warming arctic. Curr.

572 Biol. 25, 2555-2561.

573

574 Betsill, M., Gonzalez, J., \& Woods, A. (2019). The Impact of Microplastic Ingestion on the Bivalve

575 Filtration Efficiency of the Hooked Mussel (Ischadium recurvum) from the Chesapeake Bay. Research

576 Proposal for UH 1604: Honors Research Practices at Virginia Tech.

578 Bhagat, J., Nishimura, N., \& Shimada, Y. (2020). Toxicological interactions of 579 microplastics/nanoplastics and environmental contaminants: Current knowledge and future 580 perspectives. Journal of Hazardous Materials, 123913. 
583 for estimating and comparing cosinor parameters. Chronobiologia, 9, 397-439.

585 Born, M. P., \& Schüttrumpf, H. (2019, September). Microplastic in Coastal Areas-Impact of Waves, 586 Sediments and Saltwater on the Degradation Behaviour. In International Conference on Microplastic Pollution in the Mediterranean Sea (pp. 158-163). Springer, Cham.

Boullot, F., Castrec, J., Bidault, A., Dantas, N., Payton, L., Perrigault, M., Tran, D., Amzil, Z., Boudry, P., Soudant, P., Hégaret, H., Fabioux, C. (2017) Molecular Characterization of Voltage-Gated Sodium 591 Channels and Their Relations with Paralytic Shellfish Toxin Bioaccumulation in the Pacific Oyster 592 Crassostrea gigas. Mar. Drugs. 15(1): 21.

594 Box, G. E., Jenkins, G. M., Reinsel, G. C., \& Ljung, G. M. (2015). Time series analysis: forecasting and 595 control. John Wiley \& Sons.

597 Bringer, A., Thomas, H., Prunier, G., Dubillot, E., Bossut, N., Churlaud, C., Clerandeau, C., Le Bihanic, 598 F., Cachot, J. (2020a). High density polyethylene (HDPE) microplastics impair development and 599 swimming activity of Pacific oyster D-larvae, Crassostrea gigas, depending on particle 600 size. Environmental Pollution, 113978.

601

602 Bringer, A., Cachot, J., Prunier, G., Dubillot, E., Clérandeau, C., \& Thomas, H. (2020b). Experimental 603 ingestion of fluorescent microplastics by pacific oysters, Crassostrea gigas, and their effects on the 604 behaviour and development at early stages. Chemosphere, 126793. 
606 Bringer, A., Le Floch, S., Kerstan, A., \& Thomas, H. (2021). Coastal ecosystem inventory with 607 characterization and identification of plastic contamination and additives from aquaculture 608 materials. Marine Pollution Bulletin, 167, 112286.

609

610 Caputo, F., Vogel, R., Savage, J., Vella, G., Law, A., Della Camera, G., Hannon, G., Peacock, B., Mehn,

611 D., Ponti, J., Geiss, O., Aubert, D., Prina-Mello, A., Calzolai, L. (2021). Measuring particle size 612 distribution and mass concentration of nanoplastics and microplastics: addressing some analytical 613 challenges in the sub-micron size range. Journal of Colloid and Interface Science, 588, 401-417.

614

615 Castrec, J., Soudant, P., Payton, L., Tran, D., Miner, P., Lambert, C., Goïc, N. Le, Huvet, A., Quillien, V., 616 Boullot, F., Amzil, Z., Hégaret, H., Fabioux, C., 2018. Bioactive extracellular compounds produced by 617 the dinoflagellate Alexandrium minutum are highly detrimental for oysters. Aquatic Toxicology. 199, $618 \quad 188-198$.

620 Chmist, J., Szoszkiewicz, K., \& Drożdżyński, D. (2019). Behavioural responses of Unio tumidus 621 freshwater mussels to pesticide contamination. Archives of environmental contamination and toxicology, 77(3), 432-442.

623

CNC (Comité National de la Conchyliculture), 2016. http://www.cnc-france.com/La-Productionfrancaise.aspx (accessed July 2019).

CNC (Comité National de la Conchilyculture), 2020 ; Les statistiques. www.cnc-france.com (accessed 628 October 2020).

630 Cole, M., Lindeque, P., Halsband, C., Galloway, T.S. (2011). Microplastics as contaminants in the 631 marine environment: a review. Marine Pollution Bulletin, 62, 2588-2597. 
633 Cole, M., Galloway, T.S. (2015). Ingestion of nanoplastics and microplastics by Pacific oyster larvae.

634 Environmental Sciences Technology, 49(24), 14625-14632.

635

636 Constant, M. (2018). Source, Transfert et Devenir des microplastiques (MP) en MerMediterranee

637 Nord-Occidentale. PhD thesis. University of Perpignan-CEFREM, pp277.

638

639 Díaz-Mendoza, C., Mouthon-Bello, J., Pérez-Herrera, N. L., \& Escobar-Díaz, S. M. (2020). Plastics and 640 microplastics, effects on marine coastal areas: a review. Environmental Science and Pollution 641 Research, 1-10.

642

643 Dris, R., Lahens, L., Rocher, V., Gasperi, J., \& Tassin, B. (2016). Premières investigations sur la 644 contamination en microplastiques d'une zone urbaine. Cas de l'agglomération parisienne, vol. 12.

645

646 El-Sheekh, M. M., Ktkat, H. M., \& Hammouda, O. H. (1994). Effect of atrazine herbicide on growth, 647 photosynthesis, protein synthesis, and fatty acid composition in the unicellular green alga Chlorella 648 kessleri. Ecotoxicology and environmental safety, 29(3), 349-358.

649

650 Enders, K., Lenz, R., Stedmon, C. A., \& Nielsen, T. G. (2015). Abundance, size and polymer 651 composition of marine microplastics $\geq 10 \mu \mathrm{m}$ in the Atlantic Ocean and their modelled vertical 652 distribution. Marine pollution bulletin, 100(1), 70-81.

653

654 Eriksen, M., Maximenko, N., Thiel, M., Cummins, A., Lattin, G., Wilson, S., Hafner, J., Zellers, A., \& 655 Rifman, S. (2013). Plastic pollution in the South Pacific subtropical gyre. Marine pollution 656 bulletin, 68(1-2), 71-76. 
658 Faggiano, L., de Zwart, D., García-Berthou, E., Lek, S., \& Gevrey, M. (2010). Patterning ecological risk 659 of pesticide contamination at the river basin scale. Science of the Total Environment, 408(11), 23196602326.

661

662 France Agrimer, 2020. Chiffres clés des filières pêche et aquculture en France, en 2020 (access in 663 February).

664 https://www.franceagrimer.fr/fam/content/download/64767/document/CC\%20pêche\%20aqua\%20 665 FR.pdf?version=22021).

666

667 Gall, S. C., \& Thompson, R. C. (2015). The impact of debris on marine life. Marine pollution 668 bulletin, 92(1-2), 170-179.

669

670 Gamain, P., Gonzalez, P., Cachot, J., Clérandeau, C., Mazzella, N., Gourves, P. Y., \& Morin, B. (2017).

671 Combined effects of temperature and copper and S-metolachlor on embryo-larval development of 672 the Pacific oyster, Crassostrea gigas. Marine pollution bulletin, 115(1-2), 201-210.

673

674 Gardon, T., Reisser, C., Soyez, C., Quillien, V., \& Le Moullac, G. (2018). Microplastics affect energy 675 balance and gametogenesis in the pearl oyster Pinctada margaritifera. Environmental science \& 676 technology, 52(9), 5277-5286.

677

678 Gardon, T., Morvan, L., Huvet, A., Quillien, V., Soyez, C., Le Moullac, G., \& Le Luyer, J. (2020). 679 Microplastics induce dose-specific transcriptomic disruptions in energy metabolism and immunity of 680 the pearl oyster Pinctada margaritifera. Environmental Pollution, 266, 115180. 
682 Girard, S., \& Agúndez, J. A. P. (2014). The effects of the oyster mortality crisis on the economics of

683 the shellfish farming sector: Preliminary review and prospects from a case study in Marennes-Oleron

684 Bay (France). Marine Policy, 48, 142-151.

685

686 Gouthiere, L., Mauvieux, B., Davenne, D., \& Waterhouse, J. (2005). Complementary methodology in 687 the analysis of rhythmic data, using examples from a complex situation, the rythmicity of 688 temperature in night shift workers. Biological Rhythm Research, 36(3), 177-193.

689

690 Green, D. S. (2016). Effects of microplastics on European flat oysters, Ostrea edulis and their 691 associated benthic communities. Environmental pollution, 216, 95-103.

692

693 Haberkorn, H., Lambert, C., Le Goïc, N., Moal, J., Suquet, M., Guéguen, M., Sunila, I \& Soudant, P. 694 (2010). Effects of Alexandrium minutum exposure on nutrition-related processes and reproductive 695 output in oysters Crassostrea gigas. Harmful algae, 9(5), 427-439.

696

697 Haberkorn, H., Tran, D., Massabuau, J. C., Ciret, P., Savar, V., \& Soudant, P. (2011). Relationship 698 between valve activity, microalgae concentration in the water and toxin accumulation in the 699 digestive gland of the Pacific oyster Crassostrea gigas exposed to Alexandrium minutum. Marine 700 pollution bulletin, 62(6), 1191-1197.

701

702 Horton, A. A., Svendsen, C., Williams, R. J., Spurgeon, D. J., \& Lahive, E. (2017). Large microplastic 703 particles in sediments of tributaries of the River Thames, UK-Abundance, sources and methods for 704 effective quantification. Marine pollution bulletin, 114(1), 218-226. 
Horton, A.A., Vijver, M.G., Lahive, E., Spurgeon, D.J., Svendsen, C., Heutink, R., van Bodegom, P.M.,

707 Baas, J., 2018. Acute toxicity of organic pesticides to Daphnia magna is unchanged by co-exposure to

708 polystyrene microplastics. Ecotoxicol. Environ. Saf. 166, 26-34.

709

710 Ineris. (2013). Valeur guide environnementale: Chlortoluron (15545-48-9)

711 https://substances.ineris.fr/fr/substance/cas/15545-48-9/3

712

713 Islam, M. S., \& Tanaka, M. (2004). Impacts of pollution on coastal and marine ecosystems including

714 coastal and marine fisheries and approach for management: a review and synthesis. Marine pollution

715 bulletin, 48(7-8), 624-649.

716

717 Kaile, N., Lindivat, M., Elio, J., Thuestad, G., Crowley, Q. G., \& Hoell, I. A. (2020). Preliminary results

718 from detection of microplastics in liquid samples using flow cytometry. Frontiers in Marine Science, 7,

719856.

720

721 Lee, K.W., Shim, W.J., Kwon, O.Y., Kang, J.H., 2013. Size-dependent effects of micro polystyrene

722 particles in the marine copepod Tigriopus japonicus. Environmental Sciences Technology, 47 (19),

$723 \quad 11278-11283$.

724

725 Lee, D. H., Rhee, Y. J., Choi, K. S., Nam, S. E., Eom, H. J., \& Rhee, J. S. (2017). Sublethal concentrations

726 of atrazine promote molecular and biochemical changes in the digestive gland of the Pacific oyster

727 Crassostrea gigas. Toxicology and Environmental Health Sciences, 9(1), 50-58.

728

729 Lehotay SJ (2007). Determination of pesticide residues in foods by acetonitrile extraction and 730 partitioning with magnesium sulfate: collaborative study. J AOAC Int 90:485-520

731 
733 damage and other adverse effects in zebrafish Danio rerio and nematode Caenorhabditis

734 elegans. Science of the Total Environment, 619, 1-8.

735

736 Leonard, S. Dispersion des pesticides vers les eaux - Bassin de la Sèvre Niortaise et Marais Poitevin 737 Période 2004-2014, $2017 \quad$ - $\quad$ http://www.sevre-niortaise.fr/wp738 content/uploads/2017/04/etude_pesticides_SAGE_SNMP_31032017.pdf (accessed January 2020).

740 Li, X., Ke, M., Zhang, M., Peijnenburg, W. J. G. M., Fan, X., Xu, J., Zhang, Z., Lu, T., Fu, Z., \& Qian, H. 741 (2018). The interactive effects of diclofop-methyl and silver nanoparticles on Arabidopsis thaliana: 742 growth, photosynthesis and antioxidant system. Environmental pollution, 232, 212-219.

744 Long, M., Paul-Pont, I., Hegaret, H., Moriceau, B., Lambert, C., Huvet, A., Soudant, P., 2017. 745 Interactions between polystyrene microplastics and marine phytoplankton lead to species-specific 746 hetero-aggregation. Environmental Pollution, 228, 454-463.

748 Lucasson, A. (2018). Characterization and diversity of the mechanisms of the mortality syndrome affecting juveniles of Crassostrea gigas. PhD thesis. University of Montpellier, pp165. Fisheries and Aquaculture Technical Paper (FAO) eng no. 615.

754 Mai, H., Morin, B., Pardon, P., Gonzalez, P., Budzinski, H., \& Cachot, J. (2013). Environmental 755 concentrations of irgarol, diuron and S-metolachlor induce deleterious effects on gametes and 756 embryos of the Pacific oyster, Crassostrea gigas. Marine environmental research, 89, 1-8. 
761 Michels, J., Stippkugel, A., Lenz, M., Wirtz, K., \& Engel, A. (2018). Rapid aggregation of biofilm762 covered microplastics with marine biogenic particles. Proceedings of the Royal Society B, 285(1885), 76320181203.

764

765

Mottier, A., Kientz-Bouchart, V., Serpentini, A., Lebel, J. M., Jha, A. N., \& Costil, K. (2013). Effects of glyphosate-based herbicides on embryo-larval development and metamorphosis in the Pacific oyster, Crassostrea gigas. Aquatic toxicology, 128, 67-78.

768

Nelson, W., Tong, Y.L., Lee, J.K., Halberg, F., 1979. Methods for cosinor-rhythmometry. Chronobiologia, 6, 305-323.

Paul-Pont, I., Tallec, K., Gonzalez-Fernandez, C., Lambert, C., Vincent, D., Mazurais, D., ZamboninoInfante, J.L., Brotons, G., Lagarde, F., Fabioux, C., Soudant, P., \& Huvet, A. (2018). Constraints and priorities for conducting experimental exposures of marine organisms to microplastics. Frontiers in Marine Science, 5, 252. L., \& Gerdts, G. (2018). Arctic sea ice is an important temporal sink and means of transport for microplastic. Nature communications, 9(1), 1-12.

781 Pfannkoch, E. A., Stuff, J. R., Whitecavage, J. A., \& Moran, J. H. (2010). High Throughput Method for 782 the Determination of PAHs in Seafood by QuEChERS-SBSE-GC-MS. 
784 Phuong, N. N. (2018). Analytical developments for the characterization and quantification of 785 microplastic contamination of sedimentary and biological matrices: application to shellfish farming 786 areas in Pays de la Loire. PhD thesis. University of Nantes, pp232.

787

788

PlasticsEurope (2016) Plastics - the Facts 2016. URL http://

www.plasticseurope.de/Document/plastics-the-facts- 2016-15787.aspx

790

791

PlasticsEurope. (2020). Plastics - the facts 2020: an analysis of European plastics production, demand 792 and waste data. PlasticsEurope Internal Report 4312 (64pp.).

793 https://www.plasticseurope.org/en/resources/publications/4312-plastics-facts- 2020.

794

795

Revel, M., Châtel, A., Perrein-Ettajani, H., Bruneau, M., Akcha, F., Sussarellu, R., Rouxel, J., Costil, K.,

Decottiginies, P., Cognie, B., Lagarde, F., \& Mouneyrac, C. (2020). Realistic environmental exposure to microplastics does not induce biological effects in the Pacific oyster Crassostrea gigas. Marine pollution bulletin, 150, 110627.

799

800

Rist, S., Baun, A., Almeda, R., \& Hartmann, N. B. (2019). Ingestion and effects of micro-and nanoplastics in blue mussel (Mytilus edulis) larvae. Marine pollution bulletin, 140, 423-430.

802

803 Scargle, J. D. (1982). Studies in astronomical time series analysis. II-Statistical aspects of spectral 804 analysis of unevenly spaced data. The Astrophysical Journal, 263, 835-853.

805

806 Schwartzmann, C., Durrieu, G., Sow, M., Ciret, P., Lazareth, C. E., and Massabuau, J.-C. (2011). In situ 807 giant clam growth rate behavior in relation to temperature: a one-year coupled study of high808 frequency noninvasive valvometry and sclerochronology. Limnol. Oceanogr. 56, 1940-1951. 
810 Sokolova, I. M., \& Lannig, G. (2008). Interactive effects of metal pollution and temperature on

811 metabolism in aquatic ectotherms: implications of global climate change. Climate Research, 37(2-3), $812 \quad 181-201$.

813

814 Soletchnik, P., Bouquet, A. L., \& Mille, D. (2018). Flash Info Maline 2008-2018, ten years already... of 815 communication on the mortalities of oysters (Crassostrea gigas) and mussels (Mytilus edulis) in the 816 Pertuis Charentais. Ifremer report, pp18.

Solomon, K.R., Baker, D.B., Richards, R.P., Dixon, D.R., Klaine, S.J., LaPoint, T.W., 1996. Ecological risk assessment of atrazine in North American surface waters. Environmental Toxicology and Chemistry $15(1), 31-74$.

821

822 Song, Y. K., Hong, S. H., Jang, M., Han, G. M., \& Shim, W. J. (2015). Occurrence and distribution of 823 microplastics in the sea surface microlayer in Jinhae Bay, South Korea. Archives of environmental 824 contamination and toxicology, 69(3), 279-287.

825

826 Sow, M., Durrieu, G., Briollais, L., Ciret, P., \& Massabuau, J. C. (2011). Water quality assessment by means of HFNI valvometry and high-frequency data modeling. Environmental monitoring and assessment, 182(1-4), 155-170.

830 Stachowski-Haberkorn, S., Quiniou, F., Nedelec, M., Robert, R., Limon, G., \& de La Broise, D. (2008). 831 In-situ microcosms, a tool for assessment of pesticide impacts on oyster spat (Crassostrea 832 gigas). Ecotoxicology, 17(4), 235-245.

834 Sussarellu, R., Suquet, M., Thomas, Y., Lambert, C., Fabioux, C., Pernet, M.E.J., Goïc, N.L., Quillien, V., 835 Mingant, C., Epelboin, Y., Charlotte, C., Julien, G., Johan, R., Ika, P.-P., Philippe, S., Arnaud, H., 2016. 
836 Oyster reproduction is affected by exposure to polystyrene microplastics. Proc. Natl. Acad. Sci. U. S.

837 A. $113,2430-2435$.

838

839 Tallec, K., Huvet, A., Di Poi, C., González-Fernández, C., Lambert, C., Petton, B., Le Goic, N., Berchel, 840 M., Soudant, P., \& Paul-Pont, I. (2018). Nanoplastics impaired oyster free living stages, gametes and 841 embryos. Environmental pollution, 242, 1226-1235.

842

843 Thomas, M., Jon, B., Craig, S., Edward, R., Ruth, H., John, B., Dick, V.A., Heather, L.A., \& Matthew, S. 844 (2020). The world is your oyster: low-dose, long-term microplastic exposure of juvenile oysters. 845 Heliyon, 6(1), e03103.

846

847 Tran D., Fournier E., Durrieu G. and Massabuau J-C. (2004a) Copper detection in the asiatic clam 848 Corbicula fluminea: optimum valve closure response. Aquatic Toxicology, 66(3): 333-343.

850 Tran D., Massabuau J-C and Garnier-Laplace J. (2004b) The effect of carbon dioxide on uranium 851 bioaccumulation in the freshwater clam Corbicula fluminea. Environmental Toxicology and Chemistry, 852 23(3): 739-747.

853

854 Tran D., Bourdineaud J-P, Massabuau J-C and Garnier-Laplace J. (2005) Modulation of uranium 855 bioaccumulation by hypoxia in the freshwater clam Corbicula fluminea: induction of multixenobiotic 856 resistance protein and heat shock protein 60 in gill tissues. Environmental Toxicology and Chemistry, $857 \quad 24(9): 2278-2284$

858

859 Tran D., Fournier E., Durrieu G. and Massabuau J-C. (2007) Corbicula fluminea valve closure response 860 as sensitivity threshold to inorganic mercury contamination. Environmental Toxicology and 861 Chemistry, 26(7): 1545-1551. 
863 Tran, D., Haberkorn, H., Soudant, P., Ciret, P., \& Massabuau, J. C. (2010). Behavioral responses of

864 Crassostrea gigas exposed to the harmful algae Alexandrium minutum. Aquaculture, 298(3-4), 338-

865345.

866

867 Tran, D., Ciutat, A., Mat, A., Massabuau, J.C., Hégaret, H., Lambert, C., Le Goic, N., Soudant, P, (2015).

868 The toxic dinoflagellate Alexandrium minutum disrupts daily rhythmic activities at gene transcription,

869 physiological and behavioral levels in the oyster Crassostrea gigas. Aquatic Toxicology, 158, 41-49.

870

871 Valiente Moro, C., Bricheux, G., Portelli, C., \& Bohatier, J. (2012). Comparative effects of the 872 herbicides chlortoluron and mesotrione on freshwater microalgae. Environmental toxicology and 873 chemistry, 31(4), 778-786.

874

875 Wagner, M., Scherer, C., Alvarez-Munoz, D., Brennholt, N., Bourrain, X., Buchinger, S., Fries, E., 876 Grosbois, C., Klasmeier, J., Marti, T., Rodriguez-Mozaz, S., Urbatzka, R., Vethaak, A., Winther-Nielsen, 877 M., Reifferscheid, G., 2014. Microplastics in freshwater ecosystems: what we know and what we 878 need to know. Environ. Sci. Eur. 26 (1), 12.

879

880 Wang, F., Gao, J., Zhai, W., Liu, D., Zhou, Z., \& Wang, P. (2020). The influence of polyethylene 881 microplastics on pesticide residue and degradation in the aquatic environment. Journal of hazardous 882 materials, 394, 122517.

883 Ward, J. E.; Levinton, J.; Shumway, S.; Cucci, T. Particle sorting in bivalves: in vivo determination of 884 the pallial organs of selection. Mar. Biol. 1998, 131 (2), 283-292.

885 Ward, J. E., Zhao, S., Holohan, B. A., Mladinich, K. M., Griffin, T. W., Wozniak, J., \& Shumway, S. E. 886 (2019). Selective Ingestion and Egestion of Plastic Particles by the Blue Mussel (Mytilus edulis) and 
Eastern Oyster (Crassostrea virginica): Implications for Using Bivalves as Bioindicators of Microplastic

888 Pollution. Environmental science \& technology, 53(15), 8776-8784.

889

890 Wright, S.L., Rowe, D., Thompson, R.C., Galloway, T.S., 2013. Microplastic ingestion decreases energy

891 reserves in marine worms. Current Biology 23 (23), R1031-R1033.

892

893 Xu, X. Y., Lee, W. T., Chan, A. K. Y., Lo, H. S., Shin, P. K. S., \& Cheung, S. G. (2017). Microplastic

894 ingestion reduces energy intake in the clam Atactodea striata. Marine pollution bulletin, 124(2), 798-

895802.

896

897 Yu, H., Peng, J., Cao, X., Wang, Y., Zhang, Z., Xu, Y., \& Qi, W. (2021). Effects of microplastics and 898 glyphosate on growth rate, morphological plasticity, photosynthesis, and oxidative stress in the 899 aquatic species Salvinia cucullata. Environmental Pollution, 279, 116900.

900

901 Zhang, Q., Qu, Q., Lu, T., Ke, M., Zhu, Y., Zhang, M., Zhang, Z., Du, B., Pan, X., Sun, L., \& Qian, H. 902 (2018). The combined toxicity effect of nanoplastics and glyphosate on Microcystis aeruginosa 903 growth. Environmental Pollution, 243, 1106-1112.

904

905 Zhao, S., Zhu, L., Wang, T., \& Li, D. (2014). Suspended microplastics in the surface water of the

906 Yangtze Estuary System, China: first observations on occurrence, distribution. Marine pollution 907 bulletin, 86(1-2), 562-568.

908

909 Zhu, X., Qiang, L., Shi, H., \& Cheng, J. (2020). Bioaccumulation of microplastics and its in vivo 910 interactions with trace metals in edible oysters. Marine Pollution Bulletin, 154, 111079. 


\section{Supplementary data}

912

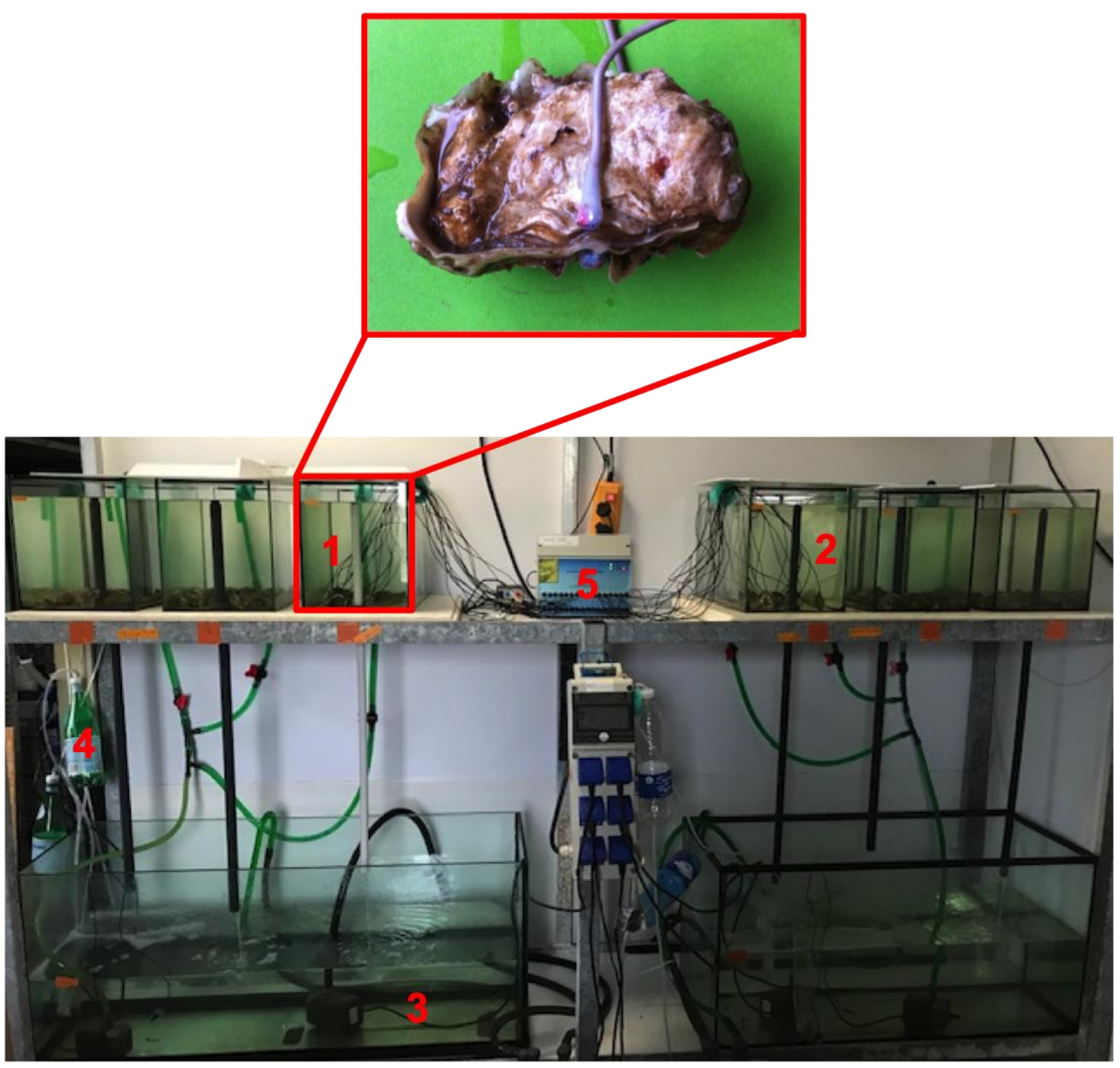

914

915 Fig. S1. Experimental design located in an experimental laboratory (LIENSs La Rochelle - CNRS). The numbers

916 correspond to: (1) experimental batch of exposed oysters equipped with valvometric electrodes (zoom

917 picture), (2) second experimental batch of exposed oysters, (3) buffer tank, (4) reduced vibrations thanks to the

918 capacitance chamber and (5) HFNI valvometer (High Frequency Non-Invasive) connected to the electrodes

919 stuck on oysters. 


\section{Chronobiological analysis}

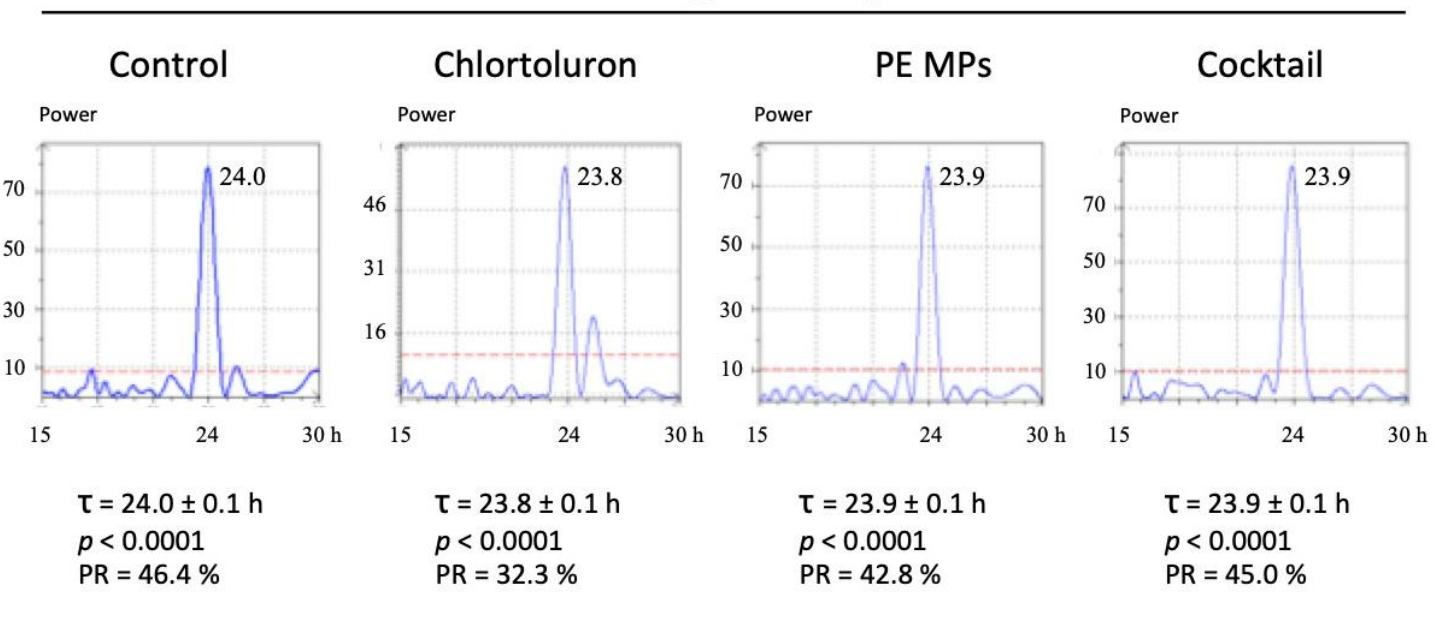

922 Fig. S2. Rhythmic valve behaviour of $C$. gigas. For each condition, the daily periodicity $(\tau)$ was determined by

923 spectral analysis (Lomb and Scargle periodogram). The $\mathrm{X}$ axis indicates the test duration in order to determine a

924 significant period. The $\mathrm{Y}$ axis displays the power (arbitral units) of the determined period. The red dotted line

925 highlights a significant period for $p$-value $=0.95$. 